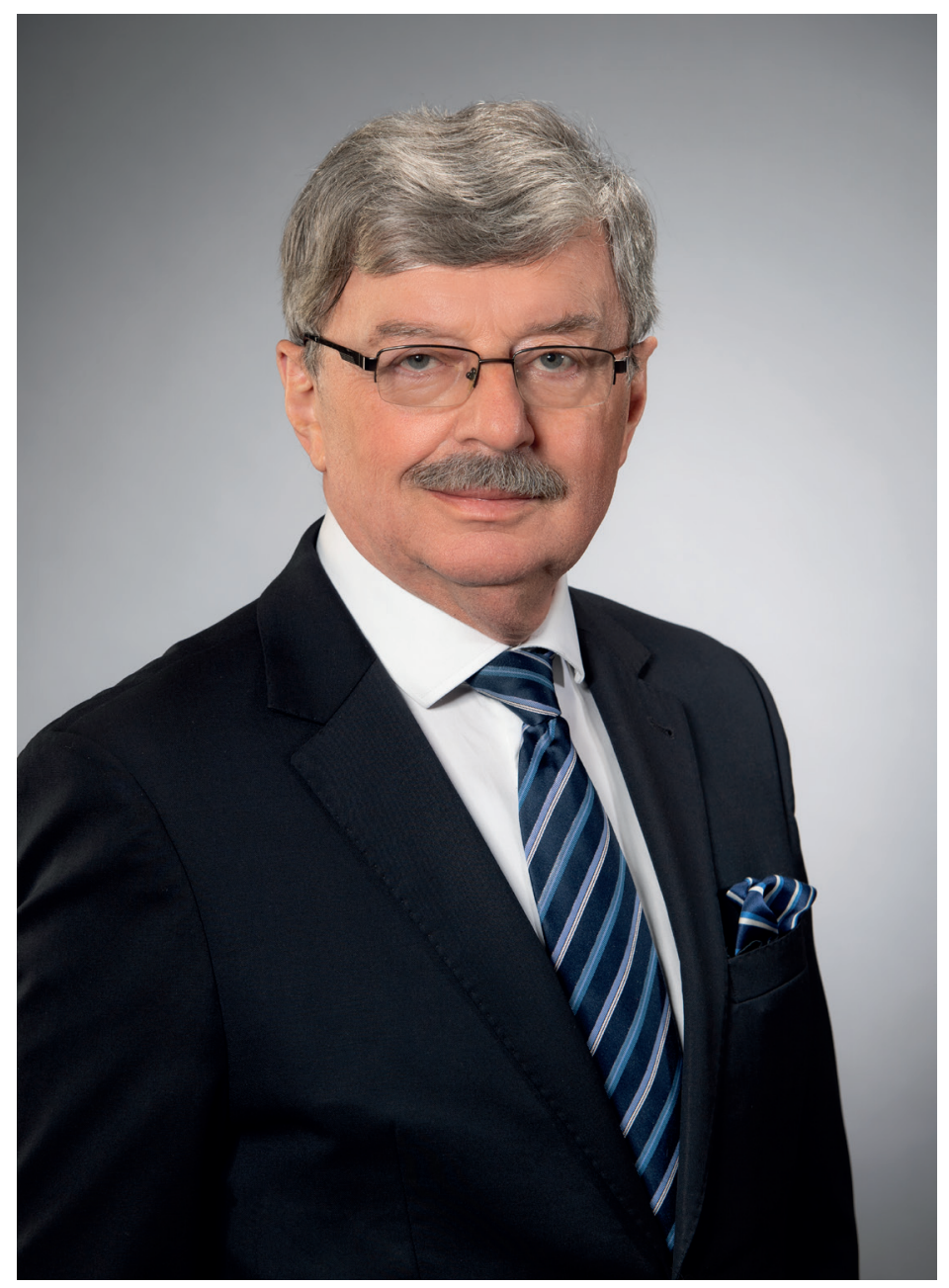

Profesor Roman BudzinOwsKi 



\section{Biografia naukowa Profesora Romana Budzinowskiego}

Jeszcze nie tak dawno, jak by się wydawało, Profesor Roman Budzinowski zaliczany był do młodszego, potem średniego pokolenia polskich prawników agrarystów. Świadomość, że już w przyszłym roku wypada jubileusz półwiecza Jego pracy akademickiej, jest dla mnie mimo wszystko zaskoczeniem, a równocześnie skłania do refleksji. Śledziłem bowiem rozwój naukowy Jubilata, wielokrotnie występowałem jako Jego recenzent. Niniejszy szkic daje mi więc doskonałą okazję do prześledzenia drogi rozwoju naukowego Profesora Budzinowskiego, uwypuklenia Jego osiągnięć i ich podsumowania.

Roman Budzinowski urodził się 21 grudnia 1950 r. w Głogowie. W 1968 r. rozpoczął studia prawnicze na Wydziale Prawa i Administracji Uniwersytetu im. Adama Mickiewicza w Poznaniu, które ukończył z wyróżnieniem w 1972 r. Po trzech miesiącach pracy jako etatowy aplikant sądowy w Sądzie Wojewódzkim w Zielonej Górze, 1 grudnia tego samego roku, podjął pracę w charakterze asystenta w Katedrze Prawa Rolnego UAM. W latach 1973-1975 odbywał pozaetatową aplikację sądową zakończoną egzaminem sędziowskim. W 1981 r. uzyskał stopień naukowy doktora nauk prawnych.

Jedną $\mathrm{z}$ zasadniczych trudności $\mathrm{w}$ próbie rzetelnego przedstawienia działalności i osiągnięć naukowych Jubilata, jakie stają przede mną jako autorem niniejszej biografii, jest bardzo szeroki zakres i stopień zróżnicowania tej aktywności. Z tego względu podjąłem się wydzielenia w działalności naukowej Profesora Budzinowskiego poszczególnych dziedzin, nurtów oraz uszeregowania ich i sukcesywnego przedstawienia. Sama natura niniejszej biografii decyduje o tym, by rozważania zacząć od w miarę syntetycznego przedstawienia ściśle naukowego dorobku Profesora Budzinowskiego.

Formacja naukowa Jubilata związana jest z poznańską szkołą prawa rolnego, której założycielem był profesor Wiktor Pawlak, promotor doktoratu, 
a więc szkołą o korzeniach bardziej administratywistycznych. Jednocześnie bliższy kontakt, jeszcze w trakcie studiów (jako seminarzysta), z profesorem Zbigniewem Radwańskim uczulił młodego adepta prawa na problematykę cywilistyczną. Będzie to widoczne w całej drodze rozwoju naukowego Jubilata, w umiejętnym łączeniu przez niego problematyki cywilistycznej i administracyjnej.

O charakterze podejmowanych przez Profesora Budzinowskiego badań przesądził natomiast związek z wybitnym poznańskim teoretykiem prawa, profesorem Zygmuntem Ziembińskim. Już na pierwszym roku studiów młody student uległ fascynacji osobą i dorobkiem profesora, został też jednym z laureatów olimpiady z logiki. Wprawdzie ostatecznie wybrał seminarium z prawa cywilnego, jednak kontakty z profesorem $\mathrm{z}$ biegiem lat uległy zacieśnieniu. To pod wpływem profesora Ziembińskiego Jubilat przygotował i opublikował w „Studiach Prawniczych” w 1977 r. artykuł dotyczący środków prawnych polityki rolnej, jak na młodego pracownika naukowego wyróżniający się, mający teoretyczny charakter.

Wydana w 1985 r. przez Państwowe Wydawnictwo Naukowe rozprawa doktorska zatytułowana Przymusowe przejmowanie nieruchomości rolnych daje wyraz temu zacięciu teoretycznemu Autora i umiejętności dokonywania syntezy. Młody doktor nie ograniczył się do analizy poszczególnych, bardzo licznych zresztą, aktów prawnych przewidujących przymusowe przejmowanie nieruchomości rolnych na własność państwa. Takie podejście byłoby zapewne łatwiejsze, ale nie przyniosłoby oczekiwanych wyników ani efektów o charakterze naukowym. Trzeba bowiem pamiętać, że rozprawa powstawała w niełatwym dla indywidualnego rolnictwa czasie, gdy problematyka ochrony własności indywidualnej, szczególnie własności rolniczej zagrożonej ,uspołecznieniem”, była zagadnieniem trudnym, a zarazem politycznie i praktycznie doniosłym. $\mathrm{Z}$ tego względu, zwłaszcza pod koniec lat 70., sam temat przymusowego przejmowania stał się - jak określił to profesor Stelmachowski - bardzo ,gorący”.

Dlatego Jubilat wybrał drogę trudniejszą, ale zapewniającą bardziej użyteczne, trwałe rezultaty naukowe. Otóż liczne rozwiązania z zakresu przymusowego przejmowania postanowił skonfrontować z istotą prawa własności oraz z pewnymi instytucjami znanymi europejskim porządkom prawnym już od dawna, a służącymi pozbawieniu tego prawa, jak wywłaszczenie, konfiskata i nacjonalizacja. Z tego względu przedmiotem szczegółowej analizy stały się tylko niektóre kwestie niezbędne dla tej konfrontacji. Wbrew tytułowi praca nie mieści się wyłącznie w ramach prawa publicznego. Bardzo mocno zarysowane są rozważania dotyczące prawa cywilnego, w tym prawa własności. Wprawdzie samo przymusowe przejmowanie ma dziś w Polsce 
raczej znaczenie historyczne, jednak wiele twierdzeń Autora zachowało aktualność, szczególnie w odniesieniu do relacji własność - państwo.

Żywotna także dziś jest na przykład teza, że o stopniu ochrony prawa własności świadczy łatwość przejmowania (odbierania) ziemi; im trudniej tę ziemię przejmować, tym stopień ochrony prawa własności jest większy. Nic zatem dziwnego, że rozprawa już w toku przewodu doktorskiego została przez recenzentów (profesorów Radwańskiego i Stelmachowskiego) uznana za wyróżniającą się, a wydana na jej podstawie książka zauważona i doceniona przez doktrynę. Świadczą o tym trzy recenzje opublikowane w polskich czasopismach (w tym piszącego te słowa) oraz jedna nota recenzyjna we włoskim czasopiśmie „Rivista di Diritto Agrario”. Książka uzyskała nagrodę III stopnia Ministra Nauki i Szkolnictwa Wyższego i okazała się bardzo przydatna w praktyce orzeczniczej sądów administracyjnych oraz Trybunału Konstytucyjnego.

Wchodząc głębiej w problematykę własności indywidualnej w rolnictwie, Jubilat w sposób naturalny zetknął się z problematyką gospodarstwa rolnego. Dał temu wyraz w kilku publikacjach artykułowych w pierwszej połowie lat 80 . Impulsem do podjęcia szczegółowych badań w tym zakresie był pobyt studyjny w Istituto di Diritto Agrario Internazionale e Comparato we Florencji w latach 1987-1988. Jak wiadomo, w prawie włoskim pojęcia gospodarstwa rolnego, a zwłaszcza przedsiębiorstwa rolnego mają podstawowe znaczenie, stanowią zworniki całej doktryny prawnorolnej. W rezultacie problematyka gospodarstwa rolnego w sposób generalny, rozszerzony i nowatorski została zaprezentowana w opublikowanej w 1992 r. rozprawie habilitacyjnej zatytułowanej Koncepcja gospodarstwa rolnego w prawie rolnym. Na jej podstawie Jubilat uzyskał stopień naukowy doktora habilitowanego nauk prawnych w zakresie prawa cywilnego i prawa rolnego.

Wprawdzie Autor nie uczynił ze swej rozprawy studium prawnoporównawczego, ale doskonale wykorzystał obce rozwiązania prawne i literaturę w zakresie objętym problematyką badawczą. Już samo przedstawienie konstrukcji zachodnioeuropejskich w tej dziedzinie wystarczyłoby do napisania ciekawej i wiele wnoszącej pracy. Autor wybrał jednak rozwiązanie trudniejsze - bogate materiały, którymi dysponował, potraktował w sposób ilustracyjny, jako bazę do własnych dociekań. Zrezygnował przy tym z analizy licznych w naszym ustawodawstwie definicji legalnych gospodarstwa rolnego, a skupił uwagę na określeniu pewnych prawidłowości ówczesnej działalności legislacyjnej. W rezultacie dokonał udanej próby sformułowania koncepcji gospodarstwa rolnego.

Autor bronił między innymi poglądu o ewolucji normatywnych konstrukcji gospodarstwa rolnego od ujęć przedmiotowych i statycznych do 
funkcjonalnych, o przechodzeniu w regulacji prawnej od gruntu rolnego (traktowanego już jako gospodarstwo), przez gospodarstwo rolne jako zespół różnorodnych składników, do przedsiębiorstwa (rolnego).

Zasadnicze znaczenie dla dalszego doktrynalnego traktowania gospodarstwa rolnego miało przejście od ujęcia wyłącznie przedmiotowego do ujęcia funkcjonalnego. To pierwsze odrzuca koncepcję majątku podmiotowego dość powszechnie akceptowaną w dotychczasowej literaturze. Skoro gospodarstwo rolne - według Autora - jest zespołem składników zorganizowanych w celu prowadzenia działalności rolniczej, to na uwagę zasługuje jego prawna struktura, kryteria uznania jedności składników zorganizowanych w gospodarstwo rolne oraz prawna kwalifikacja i funkcje materialnych składników tego gospodarstwa.

Ten schemat analizy przedmiotowego ujęcia gospodarstwa rolnego, nietraktowanego już jako jednostka własnościowa, powielany jest we współczesnych publikacjach z zakresu prawa rolnego. Nowość stanowiło natomiast rozwinięcie funkcjonalnego ujęcia gospodarstwa rolnego, obejmującego działalność rolniczą, organizowanie i funkcjonowanie tego gospodarstwa oraz status prawny podmiotu, który je prowadził. Dało ono impuls do podejmowania w literaturze, także przez Jubilata, takich zagadnień, jak: pojęcie działalności rolniczej, rola czynności faktycznych i prawnych (zwłaszcza umów) w procesie organizowania i funkcjonowania gospodarstwa rolnego czy status rolnika jako przedsiębiorcy.

Prezentowana tu książka była bezsprzecznie jedną z najbardziej teoretycznych prac $\mathrm{w}$ polskiej doktrynie prawa rolnego, jakie ukazały się w okresie 10 lat przed jej wydaniem. Spotkała się ona z powszechnym uznaniem, o czym świadczy choćby moja recenzja opublikowana w „Państwie i Prawie”, nota recenzyjna profesora Antonia Carrozzy w „Rivista di Diritto Agrario" oraz druga nagroda w konkursie „Państwa i Prawa” na najlepsze prace habilitacyjne (pierwszej nagrody nie przyznano). Mimo upływu niemal 30 lat od jej wydania jest ona bardzo często powoływana w literaturze.

Uzyskanie samodzielności naukowej przez Jubilata przypadło na trudny okres dla prawa rolnego i nauki o tym prawie. Zmiana ustroju społeczno-gospodarczego po 1989 r. spowodowała znaczne ograniczenie ustawodawstwa rolnego. Uchylone zostały regulacje dotyczące funkcjonowania rolnictwa w ramach gospodarki planowej, ale działaniom tym nie towarzyszyła ożywiona działalność prawodawcza w zakresie tworzenia „nowego” prawa, uwzględniającego warunki gospodarki rynkowej. „Kryzys prawa rolnego” - jak nazwał to zjawisko profesor Walerian Pańko - budził wśród agrarystów obawy co do dalszych losów tej dziedziny prawa. Głos w tej sprawie zabrał 
Jubilat, publikując serię prac, w których dowodził przejściowego charakteru zaistniałego kryzysu legislacyjnego, uważając słusznie za najlepsze remedium rozszerzenie i intensyfikację badań nad teoretycznymi aspektami systemu odrębnej regulacji rolnej.

Niewątpliwy talent Profesora Budzinowskiego do prowadzenia badań teoretycznych i formułowania na ich podstawie oryginalnych koncepcji prawnych uwidocznił się właśnie w kontekście wspomnianego kryzysu. Stał się on impulsem do podjęcia przez Jubilata zakrojonych na szeroką skalę badań dotyczących węzłowej problematyki prawa rolnego. W rezultacie powstała seria bardzo ciekawych, nowatorskich i pogłębionych prac, takich jak: Prawo rolne między historią a przyszłościa (1993), Zagadnienie funkcjonalności prawa rolnego w okresie przejściowym (1995), Czynniki rozwoju prawa rolnego (1998), Próby kodyfikacji prawa rolnego (2001), Zmiany prawa rolnego. Tendencje rozwoju (2002) czy O potrzebie refleksji teoretycznej w prawie rolnym (2005).

Prace te stanowiły zapowiedź tego, że „na warsztacie” naukowym Profesora Budzinowskiego znajduje się dzieło o charakterze wybitnie teoretycznym. Okazała się nim wydana w 2008 r. książka (zwana profesorską) zatytułowana Problemy ogólne prawa rolnego. Przemiany podstaw legislacyjnych i koncepcji doktrynalnych. Dla Autora była ona podsumowaniem, ukoronowaniem wieloletnich badań, także prawnoporównawczych, podstawowych kwestii teoretycznych istotnych dla rozwoju prawa rolnego i nauki o tym prawie, natomiast w polskiej doktrynie prawa rolnego - pierwszym całościowym opracowaniem poświęconym kwestiom teoretycznym, będącym co najmniej zarysem teorii tej dyscypliny.

Na taką pracę polska agrarystyka czekała już od dawna. Sam zresztą - na tle przemian ustrojowych rolnictwa w latach 90. - wskazywałem na potrzebę ponownego spojrzenia na prawo rolne jako dyscyplinę prawa, na problem nowego określenia tej dyscypliny, jej przedmiotu i zakresu regulacji. Jubilat dodał argumenty wynikające ze stanu polskiego prawa rolnego, pisząc: „Bez wątpienia zmiany ustawodawstwa związane z uzyskaniem przez Polskę członkostwa w Unii Europejskiej i objęcie naszego rolnictwa Wspólną Polityką Rolną otworzyły nowy etap w rozwoju prawa rolnego. Fakt ten, jak niegdyś dla A. Stelmachowskiego uchwalenie nowych kodyfikacji cywilnych, uzasadnia potrzebę podjęcia problematyki teoretycznej” (s. 12). W tych nowych warunkach - jak zauważa Jubilat - „Każdy prawnik-agrarysta musi stawić czoła nowościom, jakie przynosi prawo wspólnotowe, w tym zastanowić się nad granicami własnej dyscypliny" (s. 15).

Profesor Budzinowski z sukcesem stawił czoła temu wyzwaniu. Wskazał czynniki rozwoju regulacji prawnych dotyczących rolnictwa, w powiązaniu 
z tymi czynnikami ukazał ewolucję ustawodawstwa rolnego i na tym tle dopiero podjął próbę określenia miejsca prawa rolnego w systemie prawa oraz przemian koncepcji doktrynalnych w tym zakresie. Sa to zagadnienia ściśle ze sobą powiązane, skoro czynniki rozwoju prawa rolnego wpływają na wprowadzanie i kształt regulacji prawnych, a te z kolei stanowią podstawę do formułowania koncepcji teoretycznych dotyczących kształtowania się prawa rolnego jako gałęzi w systemie prawa. Autor nie poprzestał na przytaczaniu i opisie stanowisk doktryny, lecz miał odwagę formułowania własnych sądów i propozycji, odbiegających od dotychczas przyjmowanych w nauce.

Rozważania były prowadzone z „szerokim oddechem” przy uwzględnieniu aspektu historycznego i prawnoporównawczego. Mimo tak szerokiego oparcia na dotychczasowej doktrynie (wykaz literatury wykorzystanej $\mathrm{w}$ pracy obejmuje prawie pięćset pozycji, z tego ponad połowę stanowią pozycje zagraniczne) monografia jest na wskroś oryginalna. Otworzyła ona nowy etap rozwoju w nauce prawa rolnego w Polsce i stała się inspiracją do jej rozwoju w przyszłości. Można traktować ją jako głos w toczącej się w nauce zachodnioeuropejskiej dyskusji na temat kluczowych zagadnień teoretycznych prawa rolnego. O jej pozytywnym odbiorze świadczą dwie recenzje publikowane w czasopismach prawniczych, a także liczne cytowania w literaturze.

Zresztą wiele kwestii pokrótce tylko poruszonych w monografii Jubilat rozszerzył, pogłębił i opublikował zarówno w kraju, jak i za granicą w postaci odrębnych artykułów. W ten sposób powstał interesujący cykl prac dotyczących niezwykle aktualnych problemów teoretycznych prawa rolnego pisanych z myślą o potrzebie wzmocnienia nauki o tym prawie. Można tu wskazać przykładowo takie artykuły, jak: Sprzeczności rozwojowe prawa rolnego (2008), Współczesne tendencje rozwoju prawa rolnego (2009), Zagadnienia funkcjonalności prawa rolnego (2014) czy Wspótczesne wyzwania związane z żywnościa $i$ ich rola $w$ ksztaltowaniu polityki rolnej i prawa rolnego (2015).

Niektóre opracowania mają charakter ,ideowy”, z wyraźnie określonym przesłaniem. Warto tu wymienić takie artykuły, jak: O potrzebie nauczania prawa rolnego (2010), O potrzebie rozwoju nauki prawa rolnego (2012), Podstawowe zatożenia metodologiczne w nauce prawa rolnego (2013), O potrzebie opracowania i koncepcji Systemu Prawa Rolnego (2020). Wyrazem troski, ale także satysfakcji z rozwoju nauki prawa rolnego w Polsce w okresie 15 lat członkostwa w Unii Europejskiej jest artykuł charakteryzujący osiągnięcia polskiej agrarystyki na tle doktryny zachodnioeuropejskiej, opublikowany w języku angielskim w „CEDR Journal of Rural Law” (2020). 
Wszystkie wymienione opracowania są efektem bardzo pogłębionych studiów komparatystycznych.

Jednakże dorobku naukowego Jubilata, obejmującego ponad 200 pozycji, nie da się sprowadzić wyłącznie do teorii prawa rolnego, w tym do problematyki rozwoju tej gałęzi prawa. Wprawdzie to te badania stanowią niejako naukową wizytówkę Autora, jednak zakres Jego zainteresowań naukowych jest bardzo szeroki i zróżnicowany, różnorodna jest też forma wypowiedzi. Jubilat, oprócz wymienionych trzech monografii, jest także współautorem oraz redaktorem czterech innych, w tym jednej wydanej w Niemczech w języku angielskim (Food Security, Food Safety, Food Quality, Nomos 2016, której współautorem i współredaktorem jest profesor Ines Härtel z Uniwersytetu Viadrina we Frankfurcie nad Odrą) oraz współautorem i redaktorem (a także pomysłodawcą tematu) księgi kongresowej Unione Mondiale degli Agraristi Universitari zatytułowanej XV World Congress of Agricultural Law. Contemporary challenges of Agricultural Law: among Globalization, Regionalisation and Locality (Poznań 2018).

Bardzo różnorodna jest tematyka, zwłaszcza późniejszych, opracowań artykułowych. $Z$ biegiem czasu oprócz kontynuacji dotychczasowych nurtów badawczych (obejmujących takie zagadnienia, jak status indywidualnego gospodarstwa rolnego w ustroju społeczno-gospodarczym, umowy „rolne” w praktyce notarialnej czy zmiany generacji w rolnictwie) pojawiły się nowe, będące konsekwencją rozwoju uprawianej dyscypliny oraz efektem dojrzałości naukowej badacza. Tytułem przykładu można wskazać opracowania dotyczące problematyki dostosowawczej opublikowane na początku tego wieku, prawa żywnościowego, przyszłości Wspólnej Polityki Rolnej z perspektywy Polski czy polskich czasopism prawnorolnych na tle periodyków zachodnioeuropejskich. Nie brakuje też w tym dorobku, mimo cywilistycznego zacięcia Jubilata, opracowań z zakresu administracji rolnictwa. Wszystkie podejmowane tematy były ważne dla rozwoju nauki prawa rolnego, niektóre z nich wpłynęły na praktykę stosowania prawa. W latach 2011-2012 Jubilat był członkiem Zespołu Problemowego Komisji Kodyfikacyjnej Prawa Cywilnego (przewodniczącym Zespołu był profesor Radwański) do spraw opracowania umów o korzystanie z rzeczy i praw.

Bardzo liczną grupą publikacji są recenzje. Na ponad trzydzieści tego typu opracowań dwie trzecie stanowią recenzje książek zagranicznych - włoskich, niemieckich, hiszpańskich i angielskich. W ten sposób Jubilat przybliżał polskiemu czytelnikowi osiągnięcia doktryny zachodnioeuropejskiej.

Podsumowując, działalność naukowa Jubilata wyróżnia się wysokim poziomem teoretycznym, znaczną liczebnością, różnorodnym zakresem 
i aktualnością publikacji oraz stanowi jeden z najbardziej imponujących dorobków naukowych w polskiej agrarystyce.

Drugim, ściśle powiązanym z pierwszym, nurtem w działalności naukowej Jubilata jest Jego działalność edytorska. Profesor Budzinowski był redaktorem naukowym pięciu tomów periodyku „Prawo i Administracja” wydanych w latach 2002-2006 przez Wyższą Szkołę Biznesu w Pile. W 2007 r. doprowadził do utworzenia nowego ogólnopolskiego czasopisma z zakresu prawa rolnego (półrocznika) zatytułowanego „Przegląd Prawa Rolnego”, wydawanego przez Uniwersytet im. Adama Mickiewicza w Poznaniu, którego został redaktorem naczelnym i redaktorem naukowym. Ukazało się dotychczas 29 numerów (czasopismo punktowane - 70 pkt) i jest to obecnie jedyne czasopismo prawnorolne w Polsce. Wyróżnia się ono stopniem umiędzynarodowienia nie tylko z racji podejmowania tematów o charakterze globalnym, ale także ze względu na liczne publikacje autorów zagranicznych w ich ojczystych językach, a także autorów polskich z reguły w języku angielskim. W niektórych numerach czasopisma opracowania zagraniczne stanowią istotną część pierwszego działu, a ich autorzy wywodzą się nie tylko z krajów zachodnioeuropejskich (zwłaszcza z Niemiec, Włoch i Hiszpanii), ale także z państw Ameryki Południowej. Wpływa to oczywiście na stopień cytowalności czasopisma, a zainteresowanie artykułami publikowanymi w „Przeglądzie” widoczne jest w różnych państwach świata.

Za utworzenie „Przeglądu Prawa Rolnego” i pracę redakcyjną należy się Jubilatowi szacunek i - nie waham się użyć tych słów - wdzięczność całego środowiska polskich agrarystów. Dzięki Niemu nasze środowisko ma reprezentujące wysoki poziom naukowy miejsce do publikacji swych prac, a równocześnie wgląd w aktualną legislację i judykaturę polską i europejską w sprawach rolnych. Niezmiernie ważne i korzystne, zwłaszcza dla młodszych pracowników naukowych, są zawarte w „Przeglądzie” noty bibliograficzne zawierające informacje dotyczące europejskiej i amerykańskiej literatury, ustawodawstwa i doktryny agrarystycznej.

W mojej ocenie działalność edytorską uznać należy za jedno z ważniejszych osiągnięć w tak szerokiej przecież i różnorodnej działalności Jubilata.

Aktywność na arenie międzynarodowej to trzeci, uwieńczony licznymi sukcesami, nurt w działalności naukowej Profesora Budzinowskiego. To umiędzynarodowienie aktywności naukowej Jubilata ma kilka aspektów. Jego przejawem jest $\mathrm{z}$ jednej strony ponad trzydzieści opracowań w językach obcych, opublikowanych między innymi we Włoszech, w Niemczech, Szwajcarii, Francji i Hiszpanii, a także w Meksyku i Argentynie, z drugiej natomiast - liczne referaty wygłaszane na konferencjach zagranicznych. Opublikowane za granicą artykuly nie tylko mają charakter informacyjny, 
lecz podejmują także istotne kwestie dla rozwoju nauki prawa rolnego w skali globalnej.

Jubilat należycie wykorzystał wielokrotne pobyty badawcze, zwłaszcza w Istituto di Diritto Agrario Internazionale e Comparato we Florencji, nie tylko do własnego rozwoju naukowego, ale również do nawiązania kontaktów i współpracy naukowej z najbardziej znanymi agrarystami europejskimi i południowoamerykańskimi. We współpracy z profesorem Francesco Adornato z Uniwersytetu w Maceracie (obecnie jego rektorem) zorganizował pięć polsko-włoskich konferencji naukowych (tzw. tavole rotonde) na tematy interesujące obie strony. Z kolei z profesorem José Martínezem z Uniwersytetu w Getyndze współorganizował dwie konferencje polsko-niemieckie z zakresu istotnych zagadnień prawa rolnego. Natomiast wraz z profesor Ines Härtel z Uniwersytetu Viadrina we Frankfurcie nad Odrą współorganizował dwie konferencje poświęcone problematyce prawa żywnościowego. Również dwie konferencje zostały zorganizowane we współpracy z profesor Trinidad Vázquez Ruano i profesorem Ángelem Sánchezem Gutiérrezem z Uniwersytetu w Jaén w Hiszpanii.

Zasługą Jubilata jest włączenie do wszystkich organizowanych wydarzeń naukowych szerokiego grona polskich agrarystów z różnych ośrodków akademickich. Służyło ono promocji osiągnięć polskiej nauki prawa rolnego, a samym agrarystom umożliwiało nawiązanie własnych kontaktów. Niewątpliwie Jubilat jest obecnie najbardziej znanym i uznawanym polskim agrarystą w nauce zarówno europejskiej, jak i światowej. Świadczą o tym nie tylko jego zagraniczne publikacje czy działalność konferencyjna, lecz także udział w komitetach naukowych konferencji organizowanych za granicą oraz członkostwo w komitetach redakcyjnych kilku czasopism: „Agricoltura Istituzioni Mercati”, „Diritto Agroalimentare”, „EU Agrarian Law (The Journal of Slovak University of Agriculture in Nitra)" oraz „CEDR Journal of Rural Law”. Dzięki Jego rekomendacji wiele artykułów polskich agrarystów zostało opublikowanych w tym ostatnim czasopiśmie, wydawanym przez Europejski Komitet Prawa Rolnego (Comité Européen de Droit Rural).

Wyrazem uznania, jakim cieszy się Jubilat w środowisku międzynarodowym, było powierzenie Polskiemu Stowarzyszeniu Prawników Agrarystów, a bezpośrednio Jubilatowi jako przewodniczącemu Zarządu, organizacji XV Światowego Kongresu Prawa Rolnego pod auspicjami Unione Mondiale degli Agraristi Universitari. Kongres odbył się w Poznaniu we wrześniu 2018 r., zgromadził referentów z kilku kontynentów i został bardzo wysoko oceniony przez uczestników. Jego materialnym śladem jest wspomniana już księga kongresowa zawierająca ponad sześćdziesiąt artykułów w językach 
obcych. Oczywistym następstwem tego sukcesu stało się powierzenie po raz pierwszy polskim agrarystom organizacji XXX Europejskiego Kongresu Prawa Rolnego przez Comité Européen de Droit Rural. Kongres ten, zatytułowany ,Food sovereignity, food security and the contribution of agricultural law", odbył się w 2019 r., również w Poznaniu i został bardzo pozytywnie oceniony przez władze CEDR i uczestników.

Patrząc z perspektywy 60 lat na rozwój prawa rolnego w Polsce, mogę z całym przekonaniem stwierdzić, że o ile profesor Stelmachowski był pierwszym polskim agrarystą, który nawiązał kontakty naukowe z agrarystami Europy Zachodniej, o tyle dzięki swej działalności Profesor Budzinowski jest w tej chwili najbardziej znanym i uznawanym za granicą agrarystą polskim, zaś agraryści polscy stali się w skali międzynarodowej nie tylko uznawaną, ale też jedną z bardziej aktywnych grup naukowców specjalizujących się w problematyce prawa rolnego.

Jubilat potrafił doskonale połączyć swą, przedstawioną wyżej, szeroką aktywność naukową z działalnością dydaktyczną, która stanowi czwarty nurt Jego działalności. Na Uniwersytecie im. Adama Mickiewicza w Poznaniu prowadził różne zajęcia dydaktyczne. Były to wykłady z prawa rolnego, polityki rolnej i prawa rolnego Unii Europejskiej oraz z administracji rolnictwa, ponadto ćwiczenia $\mathrm{z}$ tych przedmiotów, a nawet - w latach 90. - ćwiczenia $\mathrm{z}$ prawa cywilnego, gdy prawo rolne w programie studiów prawniczych zostało umieszczone jako przedmiot do wyboru. Prowadził także zajęcia dla doktorantów na swym Wydziale.

Starał się, z sukcesem, zainteresować studentów wcale niełatwym przedmiotem, jakim było prawo rolne, a w początkach swojej kariery uniwersyteckiej, będąc opiekunem naukowym sekcji prawa rolnego Koła Naukowego Administratywistów, współorganizował dwa obozy naukowe. Prowadził seminaria z prawa rolnego (przez wiele lat także z prawa cywilnego) i wypromował ponad 400 magistrów.

Jako szczególne osiągnięcie Jubilata na polu dydaktyki należy uznać jego wieloletnie współautorstwo podręcznika z zakresu prawa rolnego, redagowanego najpierw przez profesora Andrzeja Stelmachowskiego, a następnie przez profesora Pawła Czechowskiego.

W przeszłości Jubilat wielokrotnie prowadził zajęcia dla aplikantów notarialnych z zakresu obrotu nieruchomościami rolnymi. Był także wykładowcą na Studium Podyplomowym dla Notariuszy. Zapoczątkował bliską współpracę między agrarystami i notariuszami, organizując w 2000 r. na zamku w Rydzynie koło Leszna pierwszą wspólną konferencję naukową połączoną ze zjazdem katedr i zakładów prawa rolnego. Współpraca obu tych środowisk jest do dziś kontynuowana. 
Znaczące sukcesy odniósł Profesor Budzinowski na polu kształcenia i opieki nad młodą kadrą naukową agrarystów, co należy uznać za piąty kierunek Jego działalności naukowej. W kierowanej przez Jubilata od 1999 r. Katedrze Prawa Rolnego (w 2020 r. przemianowanej na Zakład Prawa Rolnego, Żywnościowego i Ochrony Środowiska) pracuje obecnie pięć osób: jeden profesor, dwie osoby na stanowisku profesora uczelni i dwoje adiunktów. Pracownicy Katedry prowadzą zajęcia dydaktyczne na wszystkich kierunkach studiów uruchomionych na Wydziale (także w języku angielskim). Jubilat w latach 1996-2012 wykładał między innymi prawo rolne również na obecnym Uniwersytecie Przyrodniczym w Poznaniu (dawnej Akademii Rolniczej). Był tam kierownikiem Zakładu Prawa Rolnego, a od 2007 r. - kierownikiem Zakładu Prawa Gospodarczego i Prawa Rolnego. W ten sposób znacznie wzmocnił poznańskie środowisko prawników agrarystów.

Jubilat wypromował sześciu doktorów, z których trzech uzyskało już stopień doktora habilitowanego i etat profesora uczelni, a dwa przewody doktorskie są w toku. Był też recenzentem w trzech przewodach doktorskich i jednym postępowaniu o nadanie tytułu profesora nauk prawnych oraz przewodniczącym i członkiem kilku komisji habilitacyjnych. W kwietniu 2020 r. był także członkiem międzynarodowej komisji powołanej do przeprowadzenia konkursu na stanowisko profesora w Scuola Superiore Sant'Anna w Pizie (Włochy).

Niezmiernie bogata jest działalność organizacyjna Jubilata na własnym Uniwersytecie. Okazuje się, że nie stoi ona wcale na przeszkodzie działalności ściśle naukowej, lecz że oba te aspekty działalności można z powodzeniem pogodzić. Najlepszym tego przykładem jest właśnie biografia Profesora Budzinowskiego, w której działalność organizacyjna jest kolejnym, mocnym, pełnym sukcesów nurtem.

Już w latach 1975-1982 Jubilat był pełnomocnikiem dziekana i przewodniczącym Wydziałowej Komisji do spraw pomocy materialnej dla studentów, a w latach 1982-1984 - doradcą i pełnomocnikiem rektora do spraw pomocy materialnej oraz członkiem Uczelnianego Zespołu Socjalnego dla Studentów. W semestrze zimowym w roku akademickim 1992-1993 pełnił funkcję kierownika Zaocznego Studium Prawa, a w latach 1993-1999 sprawował urząd prodziekana Wydziału Prawa i Administracji. W tym okresie uczestniczył też w pracach Komisji Rektorskiej do spraw studenckich. Był to trudny czas organizowania masowych studiów zaocznych, dostosowania obsługi administracyjnej do potrzeb tak dużej liczby studentów, opracowania nowych programów i planów studiów.

W latach 1999-2002 Profesor Budzinowski był członkiem Komisji Prawnej Senatu UAM. Największe jednak sukcesy osiągnął, pełniąc funkcję 
dziekana Wydziału Prawa i Administracji UAM. Urząd ten sprawował Jubilat przez dwie kadencje. Był również członkiem Komisji Rektorskiej do spraw Kadr i Finansów oraz Komisji Statutowej. To dzięki zwłaszcza jego pracy macierzysty Wydział uzyskał w 2017 r., jako jedyny w Polsce, kategorię naukową A plus. W pamięci pozostaje znakomita organizacja uroczystości jubileuszowych 100-lecia Wydziału w 2019 r. By integrować absolwentów z Wydziałem, doprowadził do utworzenia Stowarzyszenia Absolwentów i Przyjaciół Wydziału Prawa i Administracji UAM, był jego członkiem-założycielem oraz pierwszym prezesem w latach 2017-2021.

Ta działalność organizacyjna Jubilata dotyczyła nie tylko macierzystego Wydziału i macierzystej Uczelni. Równie duże sukcesy odniósł Profesor Budzinowski, integrując i organizując środowisko polskich agrarystów. Jubilat jest członkiem-założycielem Polskiego Stowarzyszenia Prawników Agrarystów (od 2003 r. członkiem Zarządu, a od maja 2014 r. - przewodniczącym). Bardzo widoczna jest Jego działalność na rzecz wzmocnienia oraz integracji środowiska polskich i zagranicznych prawników agrarystów. Służy temu między innymi organizowany już po raz piąty konkurs imienia Profesora Andrzeja Stelmachowskiego na najlepsze prace naukowe z zakresu prawa rolnego. Jubilat jest też członkiem Unione Mondiale degli Agraristi Universitari. Dzięki Jego rekomendacji liczne grono polskich agrarystów zostało w bieżącym roku przyjęte do tej prestiżowej organizacji. Na XXVIII Kongresie Europejskiego Komitetu Prawa Rolnego (Comité Européen de Droit Rural), który odbył się w Poczdamie we wrześniu 2015 r., został wybrany na wiceprezydenta, a na kolejne kadencje - na Kongresie CEDR w Lille we wrześniu 2017 r. i w Poznaniu we wrześniu 2019 r.

Jubilat otrzymał ponad dwadzieścia nagród rektora za działalność naukową i organizacyjną, w tym nagrody pierwszego i drugiego stopnia, a także nagrody dziekana. Został wyróżniony srebrnym medalem „Labor omnia vincit" przez Towarzystwo im. Hipolita Cegielskiego, a w 2019 r. otrzymał godność „Lidera Pracy Organicznej” oraz statuetkę „Honorowego Hipolita” za krzewienie idei pracy organicznej. Wyrazem uznania dla pracy i postawy Jubilata jest powołanie go przez Sejm 21 listopada 2019 r. na członka Trybunału Stanu z rekomendacji Polskiego Stronnictwa Ludowego.

Reasumując: z całym przekonaniem pragnę stwierdzić, że tak bogata i różnorodna działalność naukowa, dydaktyczna i organizacyjna Profesora Budzinowskiego czyni Go tym, kogo dawniej określano prawdziwym człowiekiem uniwersytetu - homo verus academicus.

Równocześnie zasługi i osiągnięcia Profesora Budzinowskiego stawiają Go na czele polskich agrarystów, których z takim sukcesem i wielkim nakładem pracy uczynił jedną z bardziej aktywnych grup badaczy nie tylko 
w europejskiej, lecz także światowej nauce prawa rolnego. Uważam, że Profesor Budzinowski jest, obok profesora Stelmachowskiego, tym, który w największym stopniu przyczynił się do rozwoju i stabilizacji prawa rolnego jako społecznie doniosłej i ważnej w płaszczyźnie naukowej, dydaktycznej i legislacyjnej gałęzi prawa.

Mając to na uwadze, składam Ci, Drogi Jubilacie, Drogi Romanie, serdeczne podziękowania, gratulacje i najlepsze życzenia na przyszłość. Quod Deus bene vertat!

AleKSANDER LICHOROWICZ 



\section{Academic biography of Professor Roman Budzinowski}

It does not seem long ago that Professor Roman Budzinowski was a member of the younger, and then of the middle-aged generation of Polish academic lawyers. Realising that next year will mark the $50^{\text {th }}$ anniversary of the start of his university career comes as a real surprise to me and invites some reflection. I have been following his professional development and on many occasions have published reviews of his scholarly work. In writing this biography I see a perfect opportunity to trace the path followed by Professor Budzinowski throughout his professional life, and to highlight and summarise his achievements.

Roman Budzinowski was born on 21 December 1950 in Głogów. In 1968 he began law studies at the Faculty of Law and Administration of Adam Mickiewicz University in Poznań, which he completed in 1972, graduating with honours. After three months as a full-time court trainee at the Provincial Court in Zielona Góra, on 1 December of the same year, he was employed as an asystent at the Department of Agricultural Law of Adam Mickiewicz University in Poznań. From 1973 to 1975 he was also a part-time court trainee, and having passed an examination qualified as a judge. In 1981 he was awarded a $\mathrm{PhD}$ in law.

One of the main difficulties in the attempt to present an accurate account of his scholarly activities and achievements is their very wide range and diversity. Hence my decision to divide his university career into separate fields and strands, to arrange them in order and sequentially. The very nature of this biography determines that these considerations will begin with an attempt to draw together the various strands of Professor Budzinowski's strictly academic output.

Roman Budzinowski's academic background drew on the Poznań school of agricultural law founded by his doctoral dissertation supervisor, Professor Wiktor Pawlak who rooted the School in administrative law. 
However, as a participant in a seminar led by Professor Zbigniew Radwański, the young Roman became aware of the importance of civil law issues as well. These influences will be evident along the entire path of his later professional development, and in his skilful combination of civil and administrative law issues.

Yet, the nature of the research subsequently undertaken by Professor Budzinowski was determined by his relationship with an outstanding Poznań theoretician of law, Professor Zygmunt Ziembiński. From the first year of his studies, the young student became fascinated with the person and achievements of Professor Ziembiński and was one of the laureates of the logic Olympiad. He eventually opted for a seminar in civil law, but his contacts with the professor developed over the years. It was under the influence of Professor Ziembiński that Roman Budzinowski wrote an article on legal measures in agricultural policy, and published it in "Studia Prawnicze" (Legal Studies) in 1977. As for a young researcher, that article was outstandingly effective and theoretical in nature.

His doctoral dissertation, entitled "Przymusowe przejmowanie nieruchomości rolnych" (The compulsory acquisition of agricultural land) published in 1985 by Państwowe Wydawnictwo Naukowe, showed its author's inclination to theoretise and his skills in synthesis. The young Doctor of Law did not confine himself merely to the analysis of each of the very numerous legislative acts whose provisions aimed at the compulsory takeover by the State of agricultural land. Such an approach would probably have been easier, but it would not have brought the expected results and academic outcomes. It must be remembered that the dissertation was written in a period when it was not easy for private farm owners, when the protection of private property, and agricultural land in particular, was threatened with "socialisation." Therefore writing the dissertation was not only a challenging task, but its very subject was also a very important issue from the political and practical point of view. As Professor Stelmachowski stated, the issue of the compulsory acquisition of land became, especially at the end of the seventies, a very "hot" topic.

In his dissertation Professor Budzinowski decided to follow a more difficult path, but one which would ensure more useful and permanent scholarly results. He decided to contrast various solutions of the compulsory acquisition of land with the essence ownership rights and certain institutions for a long time known to the European legal system, and which served the purpose of depriving the owner of these rights. Examples of such institutions included expropriation, confiscation and nationalisation. For this reason he analysed in detail only those issues that were essential from the point of view of this contrast. Contrary to its title, the dissertation did not fall exclusively within 
the framework of public law and contained broad considerations of civil law nature including the right to ownership (property law). Although the forced takeover of land is in Poland today rather an issue of mere historical significance, many of the statements presented in the dissertation remain relevant today, especially those regarding the relationship between private ownership and the State.

For example, the thesis that the level of protection of ownership rights is determined by the ease with which land can be taken over (or away) from its owner is still valid today; or the conclusion that the more difficult it is to take over the land, the higher is the level of protection of the right of ownership. Thus, it is not surprising that at the time it was presented the dissertation was regarded as outstanding by the reviewers (Professors Radwański and Stelmachowski) and the book written on the basis of it received wide recognition and was welcomed by the doctrine. It also received three published reviews in Polish journals (one by the present author) and one review note in the Italian journal "Rivista di Diritto Agrario." The book was also awarded the third-degree prize by the Minister of Science and Higher Education and proved very useful in the jurisprudence practice of administrative courts and the Constitutional Tribunal.

While exploring in greater depth the notion of private ownership in agriculture, Professor Budzinowski naturally studied the concept of the agricultural farm and this interest was subsequently reflected in several of his publications in the first half of the eighties of the $20^{\text {th }}$ century. The motivation to undertake detailed research in this field came during his study leave spent at the Istituto di Diritto Agrario Internazionale e Comparato in Florence in 1987/1988. The stay at the Institute also contributed to his choice of subject for his habilitation dissertation a few years later. In Italian law the concepts of a farm and especially of an agricultural enterprise are basic conceptual categories, keystones of the whole doctrine of agricultural law. The habilitation dissertation entitled "The concept of an agricultural holding in agricultural law," published in 1992, addressed issues related to an agricultural farm in a general, extended and innovative way. On the basis of this dissertation Roman Budzinowski was awarded the degree of Doctor of Laws in the field of civil law and agricultural law.

Although the author took the decision not to make his dissertation a comparative legal study, he made excellent use of foreign legal solutions and relevant literature covering the research problem. Despite the fact that a mere presentation of Western European structures in this field would have sufficed to produce an interesting and highly significant work, Roman Budzinowski opted for a much more demanding approach - he treated the wealth 
of material at his disposal in an illustrative way and used it as a basis for conducting his own investigations. At the same time he gave up the analysis of the numerous legal definitions of a farm that existed in Polish legislation, and focused on determining certain regularities present in the legislative activity of those times. As a result, he succeeded in formulating the concept of an agricultural holding.

Among other things, the author defended the view of the evolution of the normative constructions of an agricultural holding from object-oriented and static to functional formulations, and of the transition in legal regulations from agricultural land (already treated as a farm) to an agricultural holding as a set of various components to an ("agricultural") enterprise.

Departing from considering an agricultural holding as a pure subject and showing its function was essential for its further doctrinal treatment. The former approach in which the concept of an agricultural holding was reduced to the assets it represented was quite commonly accepted in the literature up to that time. If, however, an agricultural holding was a group of components organised in order to carry out an agricultural activity, then what deserved attention was its legal structure, the criteria for recognising a unified set of components organised into an agricultural holding, and the legal qualification and functions of the material components of this holding.

This form of analysis based on the subjective approach to an agricultural holding no longer treated as a property unit, is repeated in contemporary publications on agricultural law. However, what constituted a complete novelty was the development of the functional approach to an agricultural holding, including the agricultural activity, the organisation and operation of a holding and the legal status of the entity that ran it. It was a stimulus for scholars, including Roman Budzinowski, to address in literature such issues as: the concept of agricultural activity, the role of factual activities and legal acts (especially entering into contracts) in the process of organising and operating an agricultural holding or the status of a farmer as an entrepreneur.

The book discussed here undoubtedly was one of the most theoretical works in the Polish doctrine of agricultural law for ten years. It met with universal recognition, reflected for example by my review published in the "Państwo i Prawo" (State and Law) journal, the review of professor Antoni Carrozza in "Rivista di Diritto Agrario," and the second prize won in the "Państwo i Prawo" competition for the best habilitation dissertation (the first prize was not awarded). Despite the passage of almost thirty years since its publication, it remains a frequently referred to publication in the literature on the subject. 
The time when Professor Budzinowski became an independent scholar coincided with a difficult period for those engaged in agricultural law and the science of this law. The transformation of the social and economic system in Poland after 1989 resulted in a significant reduction of agricultural legislation. The provisions governing the functioning of agriculture under a planned economy system were repealed, but no "new" laws were passed or at least there was no significant legislative activity in this regard that would take into account the conditions of a market economy. The "crisis of agricultural law," as Professor Walerian Pańko referred to this situation, gave rise to concerns among agricultural lawyers about the future of this field of law. It was then that Dr hab. Roman Budzinowski published a series of works in which he voiced his opinion on this matter, asserting the temporary character of the existing legislative crisis. He also rightly claimed that the best remedy to address the problem would be to extend and intensify research on the theoretical aspects of a system of separate agricultural regulation.

Professor Budzinowski's unquestionable talent for carrying out theoretical research and formulating original legal concepts based on it became evident precisely in the context of this crisis. It impelled him to start extensive research into the crucial issues of agricultural law. As a result, he authored a series of very interesting, innovative and detailed works, such as, for example: "Prawo rolne między historią a przyszłością" (Agricultural law between history and the future, 1993), "Zagadnienie funkcjonalności prawa rolnego w okresie przejściowym" (Issues of the functionality of Agricultural Law in the Transitional Period, 1995), "Czynniki rozwoju prawa rolnego" (Factors in the development of agricultural law, 1998), "Próby kodyfikacji prawa rolnego" (Attempts to codify agricultural law, 2001), "Zmiany prawa rolnego. Tendencje rozwoju" (Changes in agricultural law. Developmental tendencies, 2002), or "O potrzebie refleksji teoretycznej w prawie rolnym" (On the need for theoretical reflection in agricultural law, 2005).

These works heralded the outstandingly theoretical character of Professor Budzinowski's scholarly "workshop" which became evident in a book published in 2008 (called "professorial book") entitled "Problemy ogólne prawa rolnego. Przemiany podstaw legislacyjnych i koncepcji doktrynalnych" (General issues of agricultural law. Changes in legislative basis and doctrinal concepts). The book was a summary of his many years of study and crowned his research; it included comparative law and the basic theoretical issues important for the development of agricultural law and its legal science. At the same time it was the first comprehensive study of agricultural law in the Polish doctrine devoted to theoretical issues, amounting at least to an outline of the theory of this discipline. 
The community of Polish agricultural lawyers had long waited for such a work. I myself - in the context of the political transformation of agriculture in the nineties - pointed out the need for a new look at agricultural law as a discipline of law, and on the need for a new definition of this discipline, its subject matter and scope of regulation. Professor Budzinowski added some more arguments derived from the condition of Polish agricultural law, writing: "Undoubtedly, the changes in legislation connected with Poland's membership of the European Union and the inclusion of our agriculture in the Common Agricultural Policy have opened a new stage in the development of agricultural law. This fact, justifies the need to address theoretical issues, just as in the past A. Stelmachowski faced the enactment of a new civil code" (p. 12). In these new conditions, as he noted "Every lawyer specialising in the field of agriculture must face the innovations brought about by Community law, and also reflect on the limits of his own discipline" (p. 15).

Professor Budzinowski coped with this challenge successfully. He identified the developmental factors of legal regulations in agriculture, linked them to the evolution of agricultural legislation and against this background made an attempt to determine the place of agricultural law in the system of law and changes of doctrinal concepts arising from it. These issues are closely related to one another because the developmental factors of agricultural law influence the introduction and the shape of legal regulations, while the latter constitute the basis for the formulation of theoretical concepts in the shaping of agricultural law as a branch of the system of law. The author did not stop at quoting and describing the doctrinal standpoints, but had the courage to formulate his own judgments and proposals, differing from those accepted in the science so far.

The considerations were carried out into account the historical and comparative legal aspects. In spite of such an extensive reliance on the existing doctrine (the list of literature used in the work contains almost five hundred positions, more than half of which are foreign publications), the monograph is thoroughly original. It opened a new stage of development in the science of agricultural law in Poland, and served as an inspiration for its future expansion. The book may be regarded as a voice in the discussion going on in the Western European science about the key theoretical issues of agricultural law. Its positive reception was confirmed by two reviews published in legal journals, and very numerous citations in the literature.

What is more, many issues only briefly touched upon in the monograph were elaborated on, given a deeper analysis and then published in Poland and abroad in separate articles. In this way we received an interesting series of works on extremely current theoretical problems of agricultural law, in which 
Professor Budzinowski pointed to the need for strengthening the science of that law. Some examples of his articles include: "Sprzeczności rozwojowe prawa rolnego" (Developmental contradictions of agricultural law, 2008), "Współczesne tendencje rozwoju prawa rolnego" (Contemporary tendencies of the development of agricultural law, 2009), "Zagadnienia funkcjonalności prawa rolnego" (Issues of the functionality of agricultural law, 2014), or "Współczesne wyzwania związane z żywnością i ich rola w kształtowaniu polityki rolnej i prawa rolnego" (Contemporary food challenges and their role in shaping agricultural policy and law, 2015).

Some publications were also "ideological" in character, with a clearly defined message. To those belong for example "O potrzebie nauczania prawa rolnego" (On the need for teaching agricultural law, 2010), "O potrzebie rozwoju nauki prawa rolnego" (On the need for the development of the science of agricultural law, 2012), "Podstawowe założenia metodologiczne w nauce prawa rolnego" (Basic methodological assumptions in the science of agricultural law, 2013), "O potrzebie opracowania i koncepcji Systemu Prawa Rolnego" (Developmental needs and concepts of the "System of Agricultural Law," 2020). One of these articles, published also in English in the "CEDR Journal of Rural Law" (2020), expressed certain concerns, but also satisfaction with the state of development of the science of agricultural law in Poland in the first fifteen years of Poland's membership of the EU, and presented the achievements of Polish agricultural science against the background of Western European doctrine. All of these studies were the result of Professor Budzinowski's thorough and in-depth comparative studies.

His scientific output covering over 200 positions cannot, however, be reduced entirely to the theory of agricultural law, or to the problems of the development of this branch of law. Although these studies represent, in a certain way, the academic trademark of their author, the scope of his scholarly interests is much wider and more varied, and so are his means of expression. Apart from the three above-mentioned monographs, he is also a co-author and editor of four others, including one published in Germany in English (the other co-author and co-editor was Professor Ines Härtel from the Viadrina University in Frankfurt Oder ("Food Security, Food Safety, Food Quality," Nomos 2016). Professor Budzinowski is the co-author and editor (as well as the originator of its topic) of the Congress Book of the Unione Mondiale degli Agraristi Universitari entitled "XV World Congress of Agricultural Law. Contemporary challenges of Agricultural Law: among Globalisation, Regionalisation and Locality," Poznań 2018).

The subjects of his research work, especially in the later period, are very varied, too. In the course of time, apart from the continuation of the previous 
trends in his research (for example, concerning the status of a private farm in the socio-economic system, "agricultural" contracts in notarial practice, or generational change in agriculture) new ones appeared as a consequence of the development of the discipline and as a consequence of the scientific maturity of the researcher. For example, articles on the adjustment policy, food law, or the future of the Common Agricultural Policy from the Polish perspective, written at the beginning of this century, or on the place of Polish law and agricultural periodicals in comparison with the journals published in Western Europe. In spite of a certain inclination towards questions of civil law, Professor Budzinowski also addressed issues concerning agricultural administration. Every topic he explored and discussed was important for the development of the science of agricultural law, and some influenced the practice (of the application) of law in Poland. In the years 2011-2012 Professor Budzinowski was a member of the Civil Law Codification Committee headed by Professor Zbigniew Radwański, that worked on the drafting of contracts for the use of things and rights.

Professor Budzinowski has written over thirty reviews, most of which have subsequently been published, and more than twenty of which are reviews of foreign books - Italian, German, Spanish and English. Through those reviews he introduced Polish readers to the achievements of the Western European doctrine.

To sum up, the distinctive features of Professor Budzinowski's professional work are characterised by a high degree of theory and theoretical insight featured in a great number of publications on varied and frequently very topical issues. His scientific accomplishments are among the most impressive scholarly achievements in Polish studies in agricultural science.

The other, and closely related, main strand of Professor Budzinowski's scholarly activity is his editorial work. Professor Budzinowski was the scientific editor of five volumes of the periodical "Prawo i Administracja" (Law and Administration) published in 2002-2006 by Wyższa Szkoła Biznesu in Piła. In 2007 he succeeded in creating another nationwide agricultural law journal (biannual) entitled "Przegląd Prawa Rolnego" (Agricultural Law Review), published by the Adam Mickiewicz University in Poznań, of which he became the editor-in-chief and scientific editor. "Przegląd Prawa Rolnego" (publication indicator -70 points) has already had twenty nine consecutive issues and is currently the only Polish journal of law and agriculture. It stands out in terms of its degree of internationalisation not only because of the global character of the topics it covers, but also owing to numerous articles by foreign authors in their original languages, as well as articles by Polish authors, usually in English. In some issues of the journal, foreign studies 
constitute an important part of its first section, provided by European (mainly from Germany, Italy and Spain) as well as South American authors. This certainly has a positive impact on the journal's citation rate, and interest in the articles published in "Przegląd Prawa Rolnego" can be seen in various countries around the world.

Professor Roman Budzinowski deserves the respect and - I do not hesitate to use these words - the gratitude of the whole Polish community of agricultural lawyers for founding and editing "Przegląd Prawa Rolnego". Thanks to him there exists a quality journal in which researchers can have their articles published, and which also provides them with an insight into the current Polish and European agricultural legislation and agricultural case law. Moreover, what is also extremely important and useful, especially for younger researchers, are the bibliographical notes with information on relevant European and American literature, legislation and agricultural doctrine.

In my opinion, his editorial work should be regarded as one of the most important achievements among the wide and diverse activities of Professor Budzinowski.

He is very active in the international arena as well, which is the third strand in his academic career crowned with numerous successes. This internationalisation has several aspects. On the one hand, it manifests itself in more than thirty research papers published abroad, inter alia, in Italian, German, Swiss, French or Spanish journals, as well as in Mexico and Argentina. On the other hand, he has attended and given talks at many conferences abroad. The articles published in foreign journals are not only informative, but of international significance as they address issues relevant to the development of the science of agricultural law on a global scale.

He also managed to use his frequent study visits to other institutions, especially the Istituto di Diritto Agrario Internazionale e Comparato in Florence, for his own scientific development as well as a chance to establish contacts and scientific cooperation with the most renowned European and South American agricultural lawyers. In cooperation with Professor Francesco Adornato from the University of Macerata (currently the Rector of this University) he organised five joint Polish-Italian scientific conferences (called tavole rotonde) on topics of mutual interest. In turn, together with Professor José Martínez of the University of Göttingen he co-organised two Polish-German conferences on important issues of agricultural law. Further, in cooperation with Professor Ines Härtel from the Viadrina University in Frankfurt (Oder) he co-organised two conferences on food law. Two other conferences were organised in cooperation with Professor Trinidad Vázquez Ruano and Professor Ángel Sánchez Gutiérrez of the University of Jaén in Spain. 
Thanks to Professor Budzinowski, many Polish agricultural lawyers from various academic centres were able participate in all the scholarly events that he organised or co-organised. In this way the achievements of the Polish science of agricultural law were promoted and the scholars had the opportunity to establish their own contacts. Without any doubt Professor Roman Budzinowski is currently the most renowned and widely-recognised Polish agricultural lawyer and scholar, both in Europe and worldwide. This is evident not only in his foreign publications and conference activities, but also in his participation on the scientific committees of conferences organised abroad, as well as his membership of the editorial committees of several scientific journals, including "Agricoltura Istituzioni Mercati," "Diritto Agroalimentare," "EU Agrarian Law (The Journal of the Slovak University of Agriculture in Nitra)" and the "CEDR Journal of Rural Law." Thanks to his recommendation, a number of articles by Polish agricultural lawyers have appeared in the latter, which is a journal published by the European Committee of Agricultural Law (Comité Européen de Droit Rural).

Entrusting the Polish Association of Agricultural Lawyers, and directly Professor Budzinowski as Chairman of the Board of the Association, with the organisation of the XV World Congress on Agricultural Law under the auspices of the Unione Mondiale degli Agraristi Universitari, was an expression of the Professor's recognition by the international community. The Congress took place in Poznań in September 2018 and brought together speakers from several continents. Its organisation was highly appreciated by the participants and the Congress received a very high rating. The follow-up of the Congress was the already mentioned congress book with over sixty articles written in several congress languages. As a natural consequence of this success, the organisation of the XXX European Congress of Agricultural Law was, for the first time, entrusted by the Comite Européen de Droit Rural to Polish agriculturalists. This 2019 Congress on Food sovereignty, food security and the contribution of agricultural law was also held in Poznan and was again very well received and highly praised by the CEDR authorities and participants.

Looking back, from the perspective of 60 years, on the evolution and development of agricultural law in Poland, I can say with full conviction that while Professor Stelmachowski was the first Polish agricultural scientist to establish academic contacts with Western European agricultural lawyers, Professor Budzinowski, thanks to his work, is currently the best known and internationally most widely recognised Polish agricultural scholar, while Polish agricultural lawyers have become internationally recognised as active and a distinctive group of experts in agricultural law. 
Professor Budzinowski has managed perfectly to combine his extensive research activities with teaching, this being the fourth strand (and aspect) of his university career.

He taught a variety of subjects (lecturing and conducting classes) at the Adam Mickiewicz University in Poznań: agricultural law, agricultural policy and agricultural law of the European Union as well as agricultural administration. In the 1990s he also taught classes in civil law, when agricultural law was included as an option in the legal studies curriculum. He taught all kinds of students: undergraduates, post-graduates, and doctoral students.

In doing so, he managed with success, to interest his students in agricultural law which is not an easy subject. Right from the beginning of his university career, as an academic supervisor of the agricultural law section of the Scientific Circle of Administrative Law Students, he co-organised two study camps.

He was the supervisor of over 400 M.A. students and conducted master's seminars on agricultural law and, for a number of years, on civil law as well.

His long-term contribution to the development of a textbook on agricultural law, first edited by Professor Andrzej Stelmachowski and then by Professor Paweł Czechowski, should be recognised as his particular contribution to the teaching of agricultural law in Poland.

His teaching activities extended beyond the university and on numerous occasions he lectured on agricultural real estate trading to notary trainees, and was a lecturer at the Postgraduate Studies for Notaries. He, too, initiated a close cooperation between agricultural lawyers and notaries, and in 2000 organised the first joint scholarly conference in the castle in Rydzyna near Leszno. This conference was held together with the nationwide convention of chairs and departments of agricultural law. This cooperation between the two communities has continued to the present day.

Professor Budzinowski has had significant and important successes in the field of educating and tutoring young agricultural academics, which should be considered the fifth strand or theme of his academic work.

The Department of Agricultural Law whose chair has been held by Professor Budzinowski since 1999 (renamed the Department of Agricultural, Food and Environmental Law in 2020), currently employs five staff: one professor, two university professors and two assistant professors. The Department's staff teach students (in English too) in all fields of law offered by the Faculty. Apart from that, between 1996 and 2012 Professor Budzinowski lectured on agricultural law at the University of Life Sciences in Poznan (former University of Agriculture) where between 2007 and 2012 he held the position of Head of the Department of Economic Law and Agricultural 
Law, which has significantly contributed to the strengthening of the Poznan community of agricultural lawyers.

He was the supervisor of six $\mathrm{PhD}$ students, on three of whom there has already been already been conferred the degree of doktor habilitowany and who now hold the title of a University Professor; two other doctoral dissertations are in progress. He was also a reviewer of three post-doctoral theses and of the award of the title of professor of legal sciences, as well as chairman and member of several Habilitation committees. In April 2020, he was also a member of the international committee appointed to conduct the competition for the position of professor at the Scuola Superiore Sant'Anna in Pisa (Italy).

His organisational activities at his Alma Mater were extremely extensive and clearly they did not stand in the way of his purely scholarly work; these two aspects of his university work were successfully combined. The biography of Professor Budzinowski is the best example that such a combination is perfectly possible as his administrative commitments constituted another continuous, strong and successful strand of activities.

In the years 1975-1982 Professor Budzinowski was already the Dean's plenipotentiary and chairman of the Faculty Committee for student financial aid and in the years 1982-1984 he was the Rector's advisor and plenipotentiary for student aid and a member of the University's Student Social Unit. In the winter semester of the academic year 1992-1993 he was Head of Extra-mural Law Studies, and in the years 1993-1999 he held the office of Vice-Dean of the Faculty of Law and Administration. During that period he also worked with the Rector's Committee for Student Affairs. This was a difficult and busy time during which he had to organise extramural studies, adjust administrative services to provide for the needs of a large number of students, develop new curricula and plan the many courses offered.

In the years 1999-2002, Professor Budzinowski was a member of the Legal Affairs Committee of the Senate. His greatest successes, however, were undoubtedly achieved while serving as Dean of the Faculty of Law and Administration of Adam Mickiewicz University. He held this office for two terms. He was also a member of the Rector's Committee on Personnel and Finance and a member of the Statute Committee. It is mainly thanks to his work and involvement that in the ranking of 2017 the Faculty of his Alma Mater was awarded, as the only one in Poland, the A plus scientific category. The excellent organisation of the $100^{\text {th }}$ anniversary celebrations of the Faculty in 2019 will always be remembered as well. Wishing to integrate graduates from the Faculty, he led to the establishment of the Association of Graduates and Friends of the Faculty of Law and Administration at Adam 
Mickiewicz University, was one of its founding members and its first president in 2017-2021.

Professor Budzinowski's organisational activities exceeded the scope of his Department and his Alma Mater. He was equally successful in integrating and organising the community of Polish agricultural lawyers. He is a founding member of the Polish Association of Agricultural Lawyers (since 2003 a member of the Board, and since May 2014 the chairman). His work for the strengthening and integration of the communities of Polish and foreign agricultural lawyers is most notable. Among other projects undertaken with a view to international integration is the Professor Andrzej Stelmachowski Competition for the best research paper in agricultural law, which has already taken place five times. Professor Budzinowski is also a member of Unione Mondiale degli Agraristi Universitari. Thanks to his recommendation a large group of Polish agricultural lawyers have joined this prestigious organisation this year. At the XXVIII Congress of the European Committee for Agricultural Law (Comité Européen de Droit Rural), held in Potsdam in September 2015, Professor Budzinowski was elected Vice President, and re-appointed to the office in September 2017 at the CEDR Congress in Lille, and in Poznan in September 2019.

He has received more than twenty Rector's awards for scholarly and administrative work, including first and second degree awards, as well as Dean's awards. He was also honoured with the silver medal "Labor omnia vincit" by the Hipolit Cegielski Society, and in 2019 he received the title of "Leader of Organic Work" and the statue of "Honorary Hipolit" for promoting the idea of organic work. In recognition of his work and attitude, on 21 November 2019, on the recommendation of the Polish People's Party, the Sejm appointed him a member of the State Tribunal.

To sum up, I would like to state once again that I am convinced that such rich and varied scholarly, didactic and administrative activities make Professor Budzinowski a man who would have been in the past called - homo verus academicus - true university man.

At the same time his merits and achievements place him at the forefront of Polish agricultural lawyers who currently are, thanks to his great efforts and enormous work, among the Europe and the world's most active researchers in the science of agricultural law. I am convinced that Professor Budzinowski, alongside Professor Stelmachowski, has contributed the most to the development and stabilisation of agricultural law understood as extremely significant socially, but also as an important branch of law in the scientific, didactic and legislative sphere. 
With this in mind, I cordially thank you, Dear Roman, for all this and congratulate you on your Anniversary, with my Very Best Wishes for the future. Quod Deus bene vertat!

AleKSANDER LiCHOROWICZ 


\section{Biografia scientifica del Professor Roman Budzinowski}

Sino a non molto tempo fa il Professor Roman Budzinowski veniva annoverato tra i giusagraristi polacchi della giovane generazione, poi successivamente a quella di mezza età. Ciò nonostante, pensare che il prossimo anno decorreranno 50 anni del Suo lavoro accademico, mi lascia nello stupore, ma al contempo mi indulge alla riflessione. Ho avuto modo di seguire lo sviluppo della Sua ricerca, e più volte ho recensito le pubblicazioni da Lui preparate. Per cui il presente contributo è per me un'ottima occasione per ripercorrerne le tappe, mettere in chiara luce gli obiettivi raggiunti e farne il punto.

Roman Budzinowski è nato il 21 dicembre 1950 a Głogów. Nel 1968 ha intrapreso gli studi in scienze giuridiche presso la Facoltà di Giurisprudenza e Amministrazione dell'Università "Adam Mickiewicz” (UAM) a Poznań, laureandosi con lode nel 1972. Dopo tre mesi di lavoro come tirocinante salariato presso il Tribunale del Voivodato a Zielona Góra, il $1^{\circ}$ dicembre dello stesso anno, ha iniziato a lavorare come assistente presso la Cattedra di Diritto Agrario dell'UAM. Nel triennio 1973-1975 ha svolto un tirocinio non salariato conclusosi con un esame di giudice. Nel 1981 ha conseguito il titolo accademico di dottore di ricerca in scienze giuridiche.

Una delle difficoltà maggiori da affrontare, anche per chi scrive, nel tentativo di ripercorrere in modo accurato l'attività di ricerca e i risultati maturati dal Professore sta nel fatto che essa è molto ampia e diversificata. Da qui la mia decisione di provare a distinguere dei singoli ambiti, delle tendenze, per ordinarli, e poi presentarli. La natura stessa della presente biografia mi induce a cominciare da una presentazione assai sintetica dell'attività di ricerca strettamente intesa.

Il Professor Budzinowski si è formato presso la scuola di diritto agrario di Poznań, fondata dal professor Wiktor Pawlak, tutor della tesi di dottorato, proviene quindi da un ambiente con radici piuttosto amministrativiste. Al 
tempo stesso, grazie a un contatto assai stretto, mentre era ancora studente (ormai un laureando magistrale), con il professor Zbigniew Radwański, riesce a maturare una sensibilità verso problematiche civilistiche. Ciò sarà percepibile durante tutto il Suo percorso di ricerca, il Professore saprà congiungere, sempre con sapienza, la problematica civilistica con quella amministrativa.

Per contro, a determinare la natura della ricerca da Lui svolta è stato il legame con un eminente teorico del diritto, sempre della città di Poznań, il professor Zygmunt Ziembiński. Già durante il primo anno di studi rimase affascinato dalla persona e dalla ricerca svolta dal professore, divenne uno dei vincitori delle Olimpiadi di Logica. E anche se alla fine scelse un seminario di diritto civile, i contatti con il professor Ziembiński divennero, nel corso degli anni, sempre più intensi. Sotto la sua influenza ha preparato e pubblicato, nell'anno 1977 nella rivista "Studia Prawnicze", un articolo sugli strumenti giuridici della politica agricola, un articolo eccezionale, vista la giovane età, di carattere teorico.

La tesi di dottorato intitolata "Przymusowe przejmowanie nieruchomości rolnych" (Acquisizione coattiva degli immobili agricoli), pubblicata nel 1985 dalla casa editrice "Państwowe Wydawnictwo Naukowe", permette di intravedere proprio la predisposizione teorica dell'Autore e la capacità di sintesi. Il giovane dottore di ricerca non si è limitato ad un'analisi dei singoli, d'altronde molto numerosi, atti normativi che prevedevano l'acquisizione coattiva degli immobili agricoli nel demanio dello Stato. Un simile approccio, anche se indubbiamente più semplice, non avrebbe tuttavia portato ai risultati e agli effetti di carattere scientifico auspicati. Bisogna, infatti, tener presente che la dissertazione è stata scritta in un periodo difficile per l'agricoltura individuale, quando il tema della tutela della proprietà individuale, e nello specifico della proprietà agricola minacciata di "collettivizzazione", era un argomento difficile, ma allo stesso tempo - dal punto di vista politico e della prassi - importante. Per questo motivo, soprattutto alla fine degli anni Settanta, il tema stesso divenne, come lo definì il professor Stelmachowski, molto "caldo".

Pertanto, il Professore scelse la strada più difficile, la quale, però, gli ha garantito di arrivare a risultati scientifici più utili e duraturi. Ha deciso di mettere a confronto numerose soluzioni in materia di acquisizione coattiva con ciò che costituisce l'essenza dei diritti di proprietà, nonché con alcuni istituti noti da tempo agli ordinamenti giuridici europei, i quali, a loro volta, sono volti a sradicare questo diritto, come l'espropriazione, la confisca e la nazionalizzazione. Per questo motivo solo alcune delle questioni necessarie dal punto di vista del confronto proposto sono diventate oggetto di un'ana- 
lisi dettagliata. Contrariamente al titolo, la tesi non rientra esclusivamente nell' ambito del diritto pubblico, molto accentate risultano anche le questioni relative al diritto civile, compreso quello di proprietà. Sebbene l'acquisizione coattiva in Polonia abbia oggi un significato piuttosto storico, molte delle tesi dell'Autore hanno mantenuto la loro validità, soprattutto per quanto riguarda il rapporto proprietà-Stato.

Ancora vitale rimane ad esempio la tesi secondo la quale a determinare il grado di tutela dei diritti di proprietà sia la facilità con la quale si può acquisire (riprendersi) un terreno; più difficile risulta farlo, maggiore è la tutela dei diritti di proprietà. Non c'è quindi da meravigliarsi che già durante la procedura per conseguire il dottorato la dissertazione sia stata definita dai correlatori (i professori Radwański e Stelmachowski) come eccezionale, mentre la successiva pubblicazione, basata sulla tesi, è stata notata e apprezzata nella dottrina. A conferma vanno riportate tre recensioni pubblicate in riviste polacche (tra cui una firmata da chi scrive) e una nota di recensione apparsa sulla rivista italiana "Rivista di Diritto Agrario". Il libro, oltre a ricevere un premio di terzo grado del Ministro della Scienza e dell' Istruzione Superiore, si è rivelato di notevole utilità nella giurisprudenza dei tribunali amministrativi e della Corte costituzionale.

Nell'impegno di approfondire le questioni di proprietà individuale in agricoltura, il Professore ha avuto modo di imbattersi nella problematica riguardante l'azienda agricola. Se n'è occupato in diversi articoli nella prima metà degli anni '80, mentre il soggiorno di studio presso l'Istituto di Diritto Agrario Internazionale e Comparato di Firenze nel biennio 1987/1988 gli ha fornito lo spunto per intraprendere ricerche approfondite in questo ambito. Come risaputo, nel diritto italiano i concetti di azienda agricola, e soprattutto di impresa agricola, costituiscono le categorie concettuali di base, la chiave di volta dell'intera dottrina giusagraristica. Successivamente, la problematica dell'azienda agricola in modo generale, ampliato e innovativo è stata presentata nella tesi di abilitazione "Koncepcja gospodarstwa rolnego w prawie rolnym" (Concezione di azienda agricola nel diritto agrario), pubblicata nel 1992. La dissertazione ha permesso al Professore di conseguire il titolo accademico di "doktor habilitowany" (dottore di ricerca che ha acquisito l'abilitazione) in scienze giuridiche nel campo del diritto civile e di quello agrario.

Benché l'Autore non abbia fatto della Sua tesi uno studio di diritto comparato, ha saputo ricorrere, nell'ambito delle questioni discusse, in modo sapiente a soluzioni giuridiche e pubblicazioni straniere. Bisogna ammettere che anche una semplice presentazione delle costruzioni giuridiche di azienda agricola già presenti nell'Europa occidentale basterebbe per scrivere un lavoro interessante e molto utile. L'Autore, tuttavia, ha scelto la strada più 
difficile: ha sfruttato i ricchi materiali a sua disposizione in modo illustrativo, come punto di partenza per la propria ricerca. Così facendo, rinunciando all'analisi di numerose definizioni giuridiche di azienda agricola nella nostra legislazione, si è concentrato maggiormente sul compito di definire alcune regolarità dell'attività legislativa di allora. Di conseguenza, tentò con successo di delineare il concetto di azienda agricola.

L'Autore ha difeso, tra l'altro, le opinioni riguardanti l'evoluzione delle costruzioni legislative di un'azienda agricola da approcci oggetivi e statici a quelli funzionali, nonché su un successivo passaggio, da osservare nella regolazione giuridica, da un terreno agricolo (già trattato come azienda agricola) a un'azienda agricola intesa come insieme di vari componenti verso un'impresa (agricola).

Per un ulteriore trattamento dottrinale dell'azienda agricola di fondamentale importanza era necessario allontanarsi da un approccio esclusivamente oggetivo verso un approccio funzionale. Il primo rifiuta la concezione di patrimonio soggetivo, fino ad allora ampiamente condivisa nella letteratura. Poiché, a parere dell'Autore, essendo un'azienda agricola un insieme di componenti organizzati per svolgere l'attività, degne di nota risultano la struttura giuridica, i criteri che permettono di riconoscere $\mathrm{i}$ componenti dell'azienda come unità, la qualificazione giuridica e la funzionalità dei componenti materiali.

Un tale metodo d'analisi affiancato all'approccio oggetivo all'azienda, non più trattata da unità di proprietà, segue nelle pubblicazioni attuali di diritto agrario. Assolutamente innovativa è stata invece l'idea di sviluppare un approccio funzionale, per il quale tale azienda corrispondeva ad attività agricola, organizzazione e funzionamento della stessa, come anche lo status giuridico del soggetto che la gestisce. Ciò ha fornito uno spunto per trattare nella letteratura, anche da parte del Professore, le seguenti questioni: il concetto di attività agricola, il ruolo del lavoro da svolgere e quello dei negozi giuridici (qui soprattutto i contratti) nel processo di organizzazione dell'azienda e del funzionamento della stessa oppure lo status di agricoltore come imprenditore.

Indiscutibilmente, la tesi presentata è stata uno dei lavori più teorici apparso nella dottrina giusagrarista polacca nel periodo di 10 anni precedenti alla sua pubblicazione. Ha goduto di un ampio riconoscimento, a conferma, ad esempio, la mia recensione pubblicata su "Państwo i Prawo", la nota di recensione del professor Antonio Carrozza apparsa sulla "Rivista di Diritto Agrario" e l'assegnazione del secondo premio nel concorso indetto dalla rivista "Państwo i Prawo" per le migliori tesi di abilitazione (il primo premio non è stato aggiudicato). Nonostante siano passati quasi trent' anni dalla sua pubblicazione, viene spesso citato nella letteratura. 
Il Professore raggiunse il requisito dell'abilitazione scientifica in un periodo difficile per il diritto agrario e la scienza giusagraristica. Il cambiamento del sistema socio-economico dopo il 1989 ha comportato una significativa limitazione della legislazione agricola. Sono state abrogate le regolazioni relative al funzionamento dell'agricoltura nel sistema dell'economia pianificata, senza però dare inizio a una vigorosa attività legislativa per creare una "nuova" legge, tenendo conto delle condizioni dell'economia di mercato. La "crisi del diritto agrario", per riprendere la definizione del professor Walerian Pańko, ha sollevato preoccupazioni tra gli agraristi per il suo futuro. Il Professore è intervenuto sull'argomento pubblicando una serie di lavori in cui ha insistito sul carattere transitorio della crisi legislativa insorta, e ha giustamente ritenuto che per superarla è necessario ampliare e intensificare la ricerca sugli aspetti teorici di una regolazione agraria separata.

Bisogna ammettere che il Professor Budzinowski sia indubbiamente portato a svolgere ricerche scientifiche, le quali diventano punto di partenza per proporre concezioni giuridiche originali. Questo talento si è manifestato proprio nel contesto della crisi richiamata, la quale è diventata, poi, un impulso a intraprendere ricerche approfondite sulle questioni chiave del diritto agrario. Nasce così una serie di lavori molto interessanti, innovativi e di approfondimento, quali, ad esempio: "Prawo rolne między historią a przyszłością" (Il diritto agrario tra storia e futuro, 1993), "Zagadnienie funkcjonalności prawa rolnego w okresie przejściowym" (La questione della funzionalità del diritto agrario nel periodo di transizione, 1995), "Czynniki rozwoju prawa rolnego" (Fattori di sviluppo di diritto agrario, 1998), "Próby kodyfikacji prawa rolnego" (Tentativi di codificazione del diritto agrario, 2001), "Zmiany prawa rolnego. Tendencje rozwoju" (Cambiamenti nel diritto agrario. Tendenze di sviluppo, 2002) oppure "O potrzebie refleksji teoretycznej w prawie rolnym" (Sulla necessità di svolgere riflessioni teoriche nel diritto agrario, 2005).

A seguire le pubblicazioni richiamate si poteva intuire che il Professore stava lavorando su qualcosa di puramente teorico. Infatti, nel 2008 ha pubblicato un libro (per ottenere il titolo accademico di professore ordinario) "Problemy ogólne prawa rolnego. Przemiany podstaw legislacyjnych i koncepcji doktrynalnych" (Problemi generali del diritto agrario. Cambiamenti nei fondamenti legislativi e nelle concezioni dottrinali). Per l'Autore si trattava di una sintesi che era il culmine di molti anni di ricerca, anche di diritto comparato, sulle questioni teoriche di base importanti per lo sviluppo del diritto agrario e la scienza giusagraristica, mentre per la dottrina giusagrarisitica polacca - di un primo studio completo dedicato a questioni teoriche, il quale era più di un abbozzo teorico della disciplina. 
L'agraristica polacca attendeva da tempo un simile lavoro. Anch'io, d'altronde - sullo sfondo delle trasformazioni sistemiche dell'agricoltura negli anni novanta - ho segnalato la necessità di riconsiderare il diritto agrario come disciplina del diritto, cercando di attirare l'attenzione sul problema di fornirne una nuova definizione, del suo oggetto e ambito di regolazione. Il Professore ha aggiunto argomenti tratti dal diritto agrario polacco di allora, scrivendo: "Indubbiamente, i cambiamenti legislativi, i quali derivano dall'adesione della Polonia all'Unione europea e dall'inclusione della nostra agricoltura nella politica agricola comune, hanno portato ad aprire una nuova fase nello sviluppo di diritto agrario. Questo fatto, come una volta lo erano per A. Stelmachowski le nuove codificazioni civili, fa sorgere la necessità di soffermarsi su questioni teoriche" (p. 12). In queste nuove condizioni, come rileva il Professore, "ogni giusagrarista deve affrontare le novità portate dal diritto comunitario, riflettendo sui limiti della propria disciplina" (p. 15).

Il Professor Budzinowski ha affrontato con successo la sfida. Ha saputo indicare i fattori di sviluppo delle regolazioni giuridiche riguardanti l'agricoltura, e in relazione a loro ha mostrato l'evolversi della normativa agricola, per poi sullo sfondo tracciato tentare di definire il posto del diritto agrario nell'ordinamento giuridico, nonché come i concetti dottrinali siano cambiati al riguardo. Si tratta di questioni strettamente connesse tra loro, poiché i fattori di sviluppo del diritto agrario condizionano le regolazioni giuridiche, la loro introduzione e la forma, le quali a loro volta costituiscono la base su cui poggiano i concetti teorici riguardanti la configurazione del diritto agrario come branca del sistema giuridico. L'Autore non si è limitato a citare e riferire le prese di posizione presenti nella dottrina, ma ha avuto il coraggio di esprimere opinioni personali e proposte, assai diverse da quelle comunemente accettate.

Le considerazioni sono state svolte tenendo conto degli aspetti storici e di diritto comparato. Nonostante un largo scenario di riferimento alla già nota dottrina (l'elenco della letteratura citata nell'opera comprende quasi cinquecento pubblicazioni, di cui più della metà sono straniere), la monografia è del tutto originale. Ha permesso inoltre di aprire una nuova fase di sviluppo per la scienza giusagraristica polacca, ha dato anche uno spunto per lo sviluppo futuro. È una importante presa di posizione in una discussione presente ormai nella scienza dell'Europa occidentale sui principali problemi teorici del diritto agrario. L'opera è stata accolta positivamente, a conferma due recensioni pubblicate su riviste giuridiche, oltre che numerose citazioni in letteratura.

Successivamente, molti dei temi brevemente menzionati nella monografia sono stati ampliati, approfonditi e pubblicati in Polonia e all'estero sotto 
forma di articoli separati. Si è così creata un'interessante serie di lavori su problemi teorici di estrema attualità per il diritto agrario, redatti nell'ottica di rafforzare la scienza di tale diritto. A titolo d'esempio si possono indicare gli articoli quali: "Sprzeczności rozwojowe prawa rolnego" (Contraddizioni evolutive nel diritto agrario, 2008), "Współczesne tendencje rozwoju prawa rolnego" (Tendenze attuali di sviluppo nel diritto agrario, 2009), "Zagadnienia funkcjonalności prawa rolnego" (Problemi di funzionalità nel diritto agrario, 2014) oppure "Współczesne wyzwania związane z żywnością i ich rola w kształtowaniu polityki rolnej i prawa rolnego" (Sfide contemporanee legate agli alimenti e il loro ruolo nella definizione della politica agricola e del diritto agrario, 2015).

Alcuni studi sono "ideologici", comprendono un messaggio ben definito. Vanno citati, anche a titolo esemplificativo, i seguenti articoli: "O potrzebie nauczania prawa rolnego" (Sulla necessità di insegnare il diritto agrario, 2010), "O potrzebie rozwoju nauki prawa rolnego" (Sulla necessità di sviluppare la scienza giusagraristica, 2012), "Podstawowe założenia metodologiczne w nauce prawa rolnego" (Presupposti metodologici di base nella scienza giusagraristica, 2013), "O potrzebie opracowania i koncepcji Systemu Prawa Rolnego" (Sulla necessità di elaborare il "Trattado del diritto agrario", 2020). Un'espressione di preoccupazione, ma anche di una certa soddisfazione per lo stato di sviluppo della scienza giusagraristica polacca dopo quindici anni di adesione all'Unione Europea, è stato un articolo che discute delle conquiste dell'agraristica polacca rispetto alla dottrina dell'Europa occidentale, pubblicato anche in inglese nel "CEDR Journal of Rural Law" (2020). Tutti i contributi sopra menzionati sono frutto di studi comparativi molto approfonditi.

Tuttavia, l'attività di ricerca del Professore, di cui fanno parte oltre 200 pubblicazioni, non si riduce solo ai temi inerenti alla teoria del diritto agrario, compreso lo sviluppo dello stesso. L'ambito dei suoi interessi scientifici, benché questa ricerca sia una sorta di biglietto da visita dell'Autore, è molto ampio e variegato, e ne varia anche la forma. Oltre alle tre monografie già riportate, il Professore è anche coautore e curatore di altre quattro monografie, tra cui una pubblicata in Germania in lingua inglese (la coautrice e cocuratrice è la professoressa Ines Härtel dell’Università Europea Viadrina, Francoforte sull'Oder ("Food Security, Food Safety, Food Quality", Nomos 2016), nonché coautore ed editore (oltre che ideatore della tematica) della pubblicazione congressuale dell'Unione Mondiale degli Agraristi Universitari "XV World Congress of Agricultural Law. Contemporary challenges of Agricultural Law: among Globalization, Regionalisation and Locality", Poznań 2018). 
Gli argomenti affrontati negli articoli, soprattutto in quelli successivi, sono molto variegati. Con l'andare del tempo, oltre alle tendenze di ricerca già delineatesi (es. statuto della singola azienda nel sistema socio-economico, contratti "agricoli" nella prassi notarile oppure ricambio generazionale in agricoltura), ne sono emerse di nuove, frutto dello sviluppo della disciplina praticata e della maturità scientifica del ricercatore. A titolo d'esempio, si possono indicare gli studi concernenti i problemi di adattamento dell'ordinamento giuridico pubblicati all'inizio del secolo in corso, il diritto alimentare, il futuro della politica agricola comune dal punto di vista della Polonia, o il collocarsi di riviste di diritto agrario polacche sullo sfondo di quelle dell'Europa occidentale. Numerose sono pure, nonostante, come già ribadito, la vena civilistica del Professore, le pubblicazioni che dibattono questioni legate all'amministrazione dell'agricoltura. Tutti gli argomenti discussi risultano di fondamentale importanza per lo sviluppo della scienza giusagraristica, alcuni di essi hanno persino influenzato la prassi del diritto. Nel biennio 2011/2012 il Professore è stato membro della Commissione di Codificazione del Diritto Civile (presiedeva il prof. Z. Radwański) per la redazione dei contratti per l'uso delle cose e dei diritti.

Una parte assai numerosa delle pubblicazioni sono le recensioni. Degli oltre trenta contributi, due terzi sono recensioni di libri stranieri, redatti in italiano, tedesco, spagnolo e inglese. In questo modo, il Professore è riuscito ad avvicinare le novità della dottrina dell'Europa occidentale al pubblico polacco.

Per riassumere, l'attività di ricerca del Professore eccelle per un alto livello teorico, un'ingente quantità di pubblicazioni, un'ampiezza degli argomenti trattati e un'attualità dei temi affrontati, in poche parole è un lavoro di ricerca imponente, uno dei più impressionanti dell'agraristica polacca.

Il secondo filone dell'attività scientifica del Professore, in stretta connessione col primo, è la sua attività editoriale.

Il Professor Budzinowski è stato redattore scientifico di cinque volumi della rivista "Prawo i Administracja" pubblicati negli anni 2002-2006 dall'editore "Wyższa Szkoła Biznesu" (Piła). Nel 2007 grazie ai Suoi sforzi è stata istituita una nuova rivista nazionale di diritto agrario "Przegląd Prawa Rolnego", pubblicata con cadenza di sei mesi, edita dall'UAM, di cui è diventato caporedattore e redattore scientifico. Finora sono stati pubblicati 29 numeri consecutivi (la rivista è quotata 70 punti ministeriali). Attualmente è l'unica rivista di diritto agrario in Polonia. Si distingue per un elevato grado di internazionalizzazione, non solo perché tratta argomenti di carattere globale, ma anche perché ospita numerose pubblicazioni di autori stranieri redatte nella lingua madre, oltre che di autori polacchi, di solito in 
inglese. In alcuni volumi della rivista, i contributi stranieri costituiscono una parte significativa all'interno della prima sezione e i loro autori provengono non solo dai Paesi dell'Europa occidentale (in particolare Germania, Italia e Spagna), ma anche dal Sud America. Ciò incide ovviamente sull'indice di citazione, mentre l'interesse per gli articoli pubblicati è percepibile in vari Paesi del mondo.

Per la fondazione della rivista "Przegląd Prawa Rolnego" e per il lavoro editoriale svolto, il Professore merita rispetto e - non esito ad affermarlo - gratitudine da parte dell'intera comunità degli agraristi polacchi. Grazie a Lui, si è creato uno spazio di alto livello scientifico dove possiamo pubblicare i lavori e, allo stesso tempo, accedere all'attuale legislazione e giurisprudenza polacca, nonché quella europea in materia agraria. Estremamente importanti e utili, soprattutto per gli accademici più giovani, sono pure le note bibliografiche con informazioni sulla letteratura, la legislazione e la dottrina agraria europea e americana.

L'attività editoriale, a mio avviso, va valutata come uno dei risultati più importanti raggiunti di fronte a un'attività così ampia e diversificata del Professore.

L'impegno in ambito internazionale è il terzo filone del lavoro svolto dal Professore, coronato da numerosi successi. Ingloba vari aspetti. Da un lato si tratta di oltre trenta contributi in lingue straniere, pubblicati, tra l'altro, in Italia, Germania, Svizzera, Francia e Spagna, oltre che in Messico e Argentina; dall'altro, invece, di numerosi interventi presentati durante conferenze presso sedi universitarie straniere. Gli articoli pubblicati all'estero non sono solo di carattere informativo, ma sollevano questioni importanti per lo sviluppo della scienza giusagraristica su scala globale.

Il Professore ha sfruttato i Suoi molteplici soggiorni di ricerca, in particolare presso l'Istituto di Diritto Agrario Internazionale e Comparato di Firenze, non solo per il proprio sviluppo, ma anche per stabilire contatti e collaborazioni con i più famosi agraristi europei e sudamericani. In collaborazione con il professor Francesco Adornato dell'Università di Macerata (di cui ne è rettore), ha organizzato cinque conferenze scientifiche congiunte italo-polacche (le cosiddette tavole rotonde) su argomenti di interesse per entrambe le parti. A sua volta, con il professor Jose Martínez dell'Università di Gottinga, ha coorganizzato due conferenze polacco-tedesche su importanti questioni di diritto agrario. In più, in collaborazione con la professoressa Ines Härtel dell'Università Europea Viadrina, Francoforte sull'Oder, ha coorganizzato due conferenze dedicate al diritto alimentare. Infine, sono state organizzate altre due conferenze in collaborazione con la professoressa Trinidad Vázquez Ruano e il professor Ángel Sánchez Gutiérrez dell’Università di Jaén in Spagna. 
Inoltre, il Professore ha saputo coinvolgere numerosi agraristi polacchi provenienti da vari atenei negli incontri organizzati. Grazie a ciò ha promosso la scienza giusagraristica polacca, dando modo agli agraristi di stabilire contatti. Senza nessun dubbio, il Professore è attualmente l'agrarista polacco più famoso e rinomato dagli scienziati in Europa e nel mondo. Ne sono la prova non solo le sue pubblicazioni e attività congressuali straniere, ma anche il fatto di essere membro di comitati scientifici di convegni organizzati all'estero, nonché di comitati editoriali di diverse riviste: "Agricoltura Istituzioni Mercati", "Diritto Agroalimentare", "EU Agrarian Law (The Journal of Slovak University of Agriculture in Nitra)", come anche "CEDR Journal of Rural Law". Grazie alla Sua raccomandazione, molti articoli di agraristi polacchi sono stati pubblicati in quest'ultima rivista, edita dal Comité Européen de Droit Rural.

Il riconoscimento di cui gode il Professore in ambito internazionale è stato espresso anche con l'affidare all'Associazione Polacca dei Giusagraristi e nello specifico al Professore in qualità di Presidente del Consiglio, il compito di organizzare il XV Congresso Mondiale di Diritto Agrario sotto l'egida dell'Unione Mondiale degli Agraristi Universitari. Il congresso si è svolto a Poznań nel mese di settembre del 2018, ha riunito relatori da diversi continenti ed è stato molto apprezzato dai partecipanti. La sua traccia materiale è il già citato libro congressuale contenente oltre sessanta articoli redatti in lingue straniere. Come logica conseguenza del successo ottenuto, il Comité Européen de Droit Rural ha affidato, per la prima volta, il compito di organizzare il XXX Congresso Europeo di Diritto Agrario "Food sovereignity, food security and the contribution of agricultural law" agli agraristi polacchi, che si è tenuto a Poznań nel 2019 ed è stato valutato molto positivamente dalle autorità del CEDR e dai partecipanti.

Guardando indietro, dalla prospettiva dei 60 anni trascorsi, all'evoluzione e allo sviluppo del diritto agrario in Polonia, mi sento di affermare con piena convinzione che mentre il professor Stelmachowski è stato il primo agrarista polacco che ha stabilito contatti scientifici con gli agraristi dell'Europa occidentale, il Professor Budzinowski, grazie al lavoro fatto, è al giorno d'oggi l'agrarista polacco più famoso e riconosciuto all'estero, inoltre gli agraristi polacchi sono diventati non solo conosciuti a livello internazionale, ma anche uno dei gruppi più attivi di scienziati specializzati in diritto agrario.

Il Professore ha saputo coniugare alla perfezione un così importante impegno di ricerca, di cui sopra, con l'attività didattica, che è il quarto filone del Suo lavoro accademico.

Presso l'Università "Adam Mickiewicz" ha tenuto vari corsi di insegnamento (di diverse materie): ha insegnato Diritto Agrario, Politica Agricola 
e Diritto Agrario dell'Unione europea, nonché Amministrazione Agricola. Oltre ai seminari, vi erano laboratori, negli anni novanta persino di diritto civile, quando il diritto agrario veniva proposto come corso facoltativo. Il Professor Budzinowski ha tenuto anche seminari per i dottorandi, sempre presso la Facoltà di riferimento.

Tentò, con successo, di interessare gli studenti a una materia non facile, qual è il diritto agrario, e all'inizio della sua carriera universitaria, in qualità di tutor di ricerca della sezione di diritto agrario del Gruppo studentesco degli Amministrativisti ha gestito due gruppi di studio. Ha tenuto seminari di diritto agrario (per molti anni anche di quello civile) e promosso oltre 400 tesi di laurea.

Un successo di particolare rilievo del Professore è stato quello di essere, per molti anni, coautore di un manuale di diritto agrario, curato prima dal professor Andrzej Stelmachowski, e poi dal professor Paweł Czechowski.

In passato ha più volte tenuto corsi sul trasferimento degli immobili agricoli per tirocinanti notarili. Ha svolto anche docenza per un master universitario per notai. Ha intrapreso una stretta collaborazione tra agraristi e notai, organizzando nel 2000, presso il castello di Rydzyna, vicino Leszno, la prima conferenza scientifica congiunta accompagnata da un incontro di delegati di cattedre/sezioni di diritto agrario. La cooperazione di entrambi gli ambienti è tutt'oggi seguita.

Dei significativi e notevoli successi sono stati ottenuti anche negli incarichi di docenza a favore dei giovani docenti agraristi, è il quinto filone dell'attività scientifica intrapresa.

Cinque persone lavorano attualmente nella Cattedra di Diritto Agrario, diretta dal Professore dal 1999 (nel 2020 rinominata Cattedra di Diritto Agrario, Alimentare e Ambientale): un professore ordinario, due professori associati e due ricercatori. I docenti tengono corsi di didattica per tutti gli indirizzi di studio avviati presso la Facoltà (anche in inglese). Negli anni 1996-2012 ha tenuto conferenze, tra l'altro, di diritto agrario anche presso l'attuale Università dell'Ambiente di Poznań (ex Accademia Agraria). Era il capo della Sezione di diritto agrario e dal 2007 il capo della Sezione di diritto economico e diritto agrario. Ha così accresciuto in modo significativo la comunità di giusagraristi di Poznań.

Inoltre, è stato tutor di sei dottorati di ricerca, tre dei dottorandi hanno già conseguito il titolo accademico di "doktor habilitowany" (dottore di ricerca in possesso di abilitazione) e ottenuto la carica di professore associato, mentre altre due procedure per conseguire il dottorato sono in corso. In più, è stato correlatore in tre tesi di dottorato e in una procedura per il conferimento del titolo di professore in scienze giuridiche, nonché presidente e membro di 
diverse commissioni di abilitazione. Nell'aprile 2020 ha partecipato come membro della Commissione internazionale di valutazione della procedura selettiva per la copertura di una posizione di Professore presso la Scuola Superiore Sant'Anna di Pisa (Italia).

L'attività organizzativa presso l'università di riferimento è estremamente ricca, e, a quanto pare, non è poi di ostacolo al lavoro di ricerca, entrambi si possono conciliare con successo. Ne è di esempio la biografia del Professore, dove l'impegno organizzativo è un'altra tendenza forte e di successo.

Già negli anni 1975-1982 è diventato delegato del Preside della Facoltà e presidente della Commissione Finanze a sostegno degli studenti, e negli anni 1982-1984 anche consigliere e rappresentante del Rettore per il sostegno finanziario e membro del Gruppo Universitario Erogazione Benefici e Contributi agli Studenti. Nel semestre invernale nell'anno accademico 1992-1993 è stato Preside dei Corsi Serali di Giurisprudenza, e negli anni 1993-1999 è stato Vicepreside della Facoltà di Giurisprudenza e Amministrazione. In quel periodo ha inoltre partecipato ai lavori della Commissione Rettorale per le questioni studentesche, dove bisognava far fronte a un difficile compito di organizzare corsi serali di massa, adattare i servizi amministrativi alle esigenze di un numero elevato di studenti, elaborare nuovi programmi e piani di studio, ecc.

Negli anni 1999-2002 è stato membro della Commissione Giuridica del Senato dell'UAM. Tuttavia, i maggiori successi sono stati senza dubbio ottenuti mentre ha ricoperto l'incarico di Preside della Facoltà di Giurisprudenza e Amministrazione dell'Università “Adam Mickiewicz". L'incarico è stato svolto per due mandati. Inoltre ha partecipato alla Commissione Rettorale per le Risorse Umane e le Finanze e della Commissione Statutaria. È grazie soprattutto al suo lavoro che nel 2017, la Facoltà, ha ottenuto la categoria ministeriale A plus (l'unica ad averla ottenuta in Polonia). Impressa nella memoria rimane un'eccellente organizzazione delle celebrazioni del centenario della Facoltà nel 2019. Per venire incontro a un bisogno di integrare i laureati con la Facoltà ha portato a fondare l'Associazione dei Laureati e Amici della Facoltà di Giurisprudenza e Amministrazione dell'UAM, ne è stato membro fondatore e primo presidente negli anni 2017-2021.

L'attività organizzativa non riguardava però solo la Facoltà e l'Alma Mater. Altrettanto importanti sono i successi che è riuscito a ottenere integrando e organizzando l'ambiente degli agraristi polacchi. È un membro fondatore dell'Associazione Polacca dei Giusagraristi (dal 2003 membro del Consiglio e da maggio 2014 presidente). Molto percepibile è l'attività svolta per rafforzare e integrare la comunità di giusagraristi polacchi e stranieri. A ciò è servito, tra l'altro, il fatto di organizzare il quinto ormai concorso in 
onore del professor Andrzej Stelmachowski per i migliori lavori di ricerca in diritto agrario. Ė anche membro dell'Unione Mondiale degli Agraristi Universitari. Grazie alla sua raccomandazione, nell'anno corrente un numeroso gruppo di agraristi polacchi è stato accolto a far parte di questa prestigiosa organizzazione. Durante il XXVIII Congresso del Comité Européen de Droit Rural, tenutosi a Potsdam nel settembre 2015, è stato eletto vicepresidente, riconfermato, poi, per i successivi mandati ai Congressi CEDR di Lille (settembre 2017) e di Poznań (settembre 2019).

Ha ricevuto oltre venti premi del Rettore per l'attività scientifica e organizzativa, tra cui premi di primo e secondo grado, oltre ai premi del Preside. È stato insignito della medaglia d'argento "Labor omnia vincit" dalla Società "Hipolit Cegielski", e nel 2019 ha ricevuto la Dignità di "Leader of Organic Work" e la statuetta di "Honorary Hipolit" per aver promosso l'idea del lavoro organico. Un'espressione di riconoscimento per il lavoro e l'atteggiamento è la nomina da parte della Camera dei Deputati polacca, il 21 novembre 2019, a membro del Tribunale di Stato su raccomandazione del partito polacco "Polskie Stronnictwo Ludowe".

In sintesi: vorrei dire con piena convinzione che un'attività scientifica, didattica e organizzativa così ricca e diversificata come quella svolta dal Professor Budzinowski fa di Lui, come si diceva una volta, un vero uomo dell'università - homo verus academicus.

Al contempo, i meriti e i successi ottenuti, lo mettono al primo posto tra gli agraristi polacchi, dei quali, con molto successo e grazie a una mole di lavoro svolto, ha fatto uno dei gruppi di ricercatori più attivi non solo in Europa, ma anche nella scienza giusagraristica mondiale. Credo che il Professor Budzinowski sia, accanto al professor Stelmachowski, colui che ha maggiormente contribuito allo sviluppo e al confermarsi del diritto agrario come branca del diritto estremamente significativa e importante in ambito scientifico, didattico e legislativo.

Detto ciò, vorrei estendere i miei più sentiti ringraziamenti, congratulazioni e migliori auguri a Te, Caro Romano, per il futuro. Quod Deus bene vertat! 